\title{
Occurrence of heatwave in Korea by the displacement of South Asian high
}

\author{
Yumi Cha ${ }^{1}$. JaeWon Choi ${ }^{2}$ Eung-Sup Kim ${ }^{3}$ Joong-Bae Ahn ${ }^{4}$ (D)
}

Received: 19 April 2021 / Accepted: 26 September 2021 / Published online: 10 October 2021

(c) The Author(s) 2021

\begin{abstract}
The South Asian high (SAH) index was defined using the $200 \mathrm{hPa}$ geopotential height for 1973-2019. Of the movements of the SAH center in the north-south, east-west, northwest-southeast, and southwest-northeast directions, the movements in the northwest-southeast direction showed the highest positive correlation with heatwave days (HWDs) in South Korea. Thirteen years with the highest values in the northwestward shift of the SAH (positive SAH years) and 13 years with the highest values in the southeastward shift of the SAH (negative SAH years) were selected from a time series of SAH indices from which the linear trend was removed, and the differences between these two groups were analyzed. An analysis of vertical meridional circulation averaged along $120^{\circ}-130^{\circ}$ E showed that in the latitude zones containing Korea, anomalous downward flows with anomalous high pressures formed in the entire troposphere and coincided with a positive anomaly of air temperature and specific humidity. An analysis of stream flows and geopotential heights showed that in the positive SAH years, anomalous anticyclones developed in Korea, the North Pacific, North America, Western Europe, and the Iranian Plateau. These anticyclones had the wavenumber-5 pattern and showed more distinct barotropic vertical structures at higher altitudes, which resembled the circumglobal teleconnection (CGT) pattern. The maintenance of CGT depends on the interaction between the CGT circulation and the Indian summer monsoon (ISM), which has a major influence on the mid-latitude atmosphere. Strengthening of the ISM results in the formation of upper-level anomalous anticyclones in the northwestern Iranian Plateau and produces continuous downstream cells along the waveguide due to the Rossby wave dispersion. When diabatic heating by Indian summer monsoon precipitation is strengthened, the SAH is strengthened to the northwest of India, and a positive CGT pattern is formed. As a result, anomalous anticyclones formed in all layers of the Korean troposphere, resulting in heatwaves, tropical nights, and droughts exacerbated in South Korea.
\end{abstract}

Keywords South Asian high · Heatwave days · Circumglobal teleconnection pattern · Indian summer monsoon

\section{Introduction}

A heatwave is a period of sweltering weather, but it lacks a clear definition. A heatwave is one of the most dangerous

Joong-Bae Ahn

jbahn@pusan.ac.kr

1 National Institute of Meteorological Sciences, Seogwipo-si, Jeju, Korea

2 Institute for Basic Science, Pusan National University, Busan, Korea

3 Division of Earth Environmental System, BK21 School of Earth and Environmental Systems, Pusan National University, Busan, Korea

4 Division of Earth Environmental System, Pusan National University, Geumjeong-gu, Busan 46241, Korea natural disasters and is considered a major risk factor in South Korea that causes many casualties. Anderson and Bell (2009) reported that deaths increased by approximately $3.0 \%$ within one day of a heatwave. For example, more than 70,000 people died in 2003 when a record-breaking heatwave affected Europe (Robine et al. 2008; Schär et al. 2004), and 14,802 of these deaths occurred in France. During the period, the temperature in France exceeded $40{ }^{\circ} \mathrm{C}$ on seven consecutive days (Fink et al. 2004; Garcia-Herrera et al. 2010). In Chicago, USA, approximately 600 people died over 5 days during a heatwave in 1995 (Klinenberg, 1999; Semenza et al. 1996), and in California, more than 140 people died between July 16 and 25, 2006 (Knowlton et al. 2009). In South Korea, approximately 3,400 people died from a heatwave in 1994 (Kysely and Kim 2009).

According to future climate scenarios that address global warming, the frequencies, durations, and intensities of 
heatwaves are expected to increase due to changes in atmospheric circulation (Meehl and Tebaldi 2004; IPCC 2013). If greenhouse gas (GHG) emissions follow the current trend, the heatwave days (HWDs) will continue to increase globally and in Korea until the late 21st Century (Kim et al. 2016). Furthermore, tropical night days (TNDs) are also expected to increase as the maximum, minimum, and mean air temperatures increase (Hulme et al. 1994; Choi et al. 2007; Ha et al. 2004). Consequently, research on heatwaves has been actively pursued to reduce their impacts and ensure adequate preparation.

Studies on heatwaves in East Asia described the role of convective activity in the subtropical monsoon region, but these descriptions were not accompanied by a specific explanation of the role of interannual or intraseasonal timescale variations. Convective activities in the subtropical monsoon region related to the phase of El Niño/La Niña have continuous effects mostly during summer on an interannual timescale. On the other hand, the two primary modes (BSISO1 and BSISO2) of boreal summer intraseasonal oscillation (BSISO) moving north or northwest in the Asian monsoon region influence the generation of heatwaves and heavy rainfall depending on their phase in the intraseasonal timescale (Hsu et al. 2016, 2017; Lee et al. 2017a, 2019).

Convective activities in the tropical and subtropical monsoon regions can influence heatwaves and heavy rainfall events in mid-latitude through various teleconnections in an El Niño/La Niña phase-dependent manner (Ding et al. 2011; Lee et al. 2011, 2017b; Lee and Ha 2015; Ha et al. 2018; Lee 2018; Yeo et al. 2019). When convection is active in the western North Pacific monsoon region, a Western PacificNorth America (WPNA) teleconnection (or Pacific-Japan teleconnection) develops, and the heatwave risk increases when an anticyclonic circulation anomaly develops in East Asia (or in the Kamchatka Peninsula region) (Ding et al. 2011). In the western North Pacific (WNP) and the East Asian region, the Rossby wave spreads in a meridional direction, and Yeo et al. (2019) called this phenomenon an 'M-wave teleconnection.' The western North Pacific summer monsoon (WNPSM) exhibits active variability in the summer when El Niño/La Niña is neutral. In contrast, when convection is active in the Indian monsoon region, a circumglobal teleconnection (CGT) covering the entire northern hemisphere develops, increasing the risk of heatwaves in the East Asian region (Ding et al. 2011). When this occurs, Rossby wave dispersion is dominant in the zonal direction; hence, Yeo et al. (2019) called this a 'Z-wave teleconnection'. Furthermore, when El Niño disappears and La Niña develops, as occurred in the summers of 2010 and 2016, a WPNA teleconnection and CGT can simultaneously influence heatwaves in East Asia (Lee 2018).

The studies on heatwaves in Korea have been conducted mainly using case-centered designs (e.g., Kim et al. 1998;
Byun et al. 2006). The atmospheric structure that causes heatwaves in Korea has highly diverse spatiotemporal scales. From the perspective of large-scale atmospheric circulation, the representative cause of heatwaves in Korea is an abnormal expansion of the western North Pacific subtropical high (WNPSH). For example, heatwaves were caused when the WNPSH, which had been heading north, settled near Korea under the influence of El Niño in 1987 and typhoon "Vanessa" in 1994 (Kim et al. 1998). Furthermore, in 2004, an abnormal high air temperature event occurred in Miryang, Korea, when the axis of a warm area moved south due to WNPSH strengthening as heating in the continent was increased by reduced snow cover on the Tibetan Plateau and a secondary circulation caused by a typhoon (Byun et al. 2006). Heatwaves can also be caused in Korea by the orographic effect, such as the Föhn phenomenon. When the easterly wind from the Young-Dong region in Korea causes a Föhn phenomenon, the Young-Seo region, west of the Taebaek Mountains, has high air temperature and low relative humidity (Lee 1994). Moreover, when a westerly wind appears in the Young-Seo region, a warm and dry atmosphere is formed in the Young-Dong region by a similar principle (Kim and Hong 1996).

Yeh et al. (2018) analyzed in more detail how two teleconnection patterns influenced heatwaves in Korea. First, in the subtropical WNP region, an anticyclonic circulation anomaly was induced in Mongolia and an anticyclonic circulation anomaly in the Kamchatka Peninsula induced by convective activity exhibited blocking activity. Second, in the Indian monsoon region, anticyclonic circulation anomalies in Mongolia and the Kamchatka Peninsula were maintained by the CGT pattern induced by active convection. Both effects strengthened the anticyclonic circulation anomaly in Mongolia and the Kamchatka Peninsula. Consequently, hot and dry northerly winds flowed into Korea at the upper level, which increased the air temperature and caused heatwaves.

The South Asian high (SAH) is a strong and stable anticyclone system over the South Asian highlands in the upperlevel atmosphere during the boreal summer. It is a significant component of both the Indian and East Asian summer monsoon systems (Yeh and Gao 1979). The CGT has high spatial and temporal similarities to the teleconnection pattern incurred by the variations of the South Asian high (SAH), which is influenced by both the Indian and East Asian summer monsoon rainfall (Zhou et al. 2020).

In relation to the above studies, the present study analyzed the changes in heatwaves in Korea with respect to the displacement of the SAH. In Sect. 2, data and methodologies are introduced, and in Sect. 3, the SAH index is defined. Section 4 examines the relationships between changes in Korean heatwaves according to the SAH displacement and the causes of these changes. Finally, Sect. 5 provides a summary of the study. 


\section{Data and methodology}

\subsection{Data}

This study used surface air temperatures (SATs), precipitations, and Palmer Drought Severity Index (PDSI) data obtained at 58 in-situ weather observation stations in South Korea. These data were obtained from the Korea Meteorological Administration (KMA) website (https://www.kma. go.kr). Spatial distributions of the observation stations are presented in Fig. 1a, which shows stations distributed evenly around the country. Observational data of islands such as Ullengdo and Jejudo were excluded from the study because they exhibit unique island weather characteristics. Data obtained after 1973 were used because the number of weather observation stations increased sharply after 1973. The HWD and TND data used in this study are accessible at the KMA website (https://data.kma.go.kr/climate/). The KMA defines a HWD as the number of days when the daily maximum temperature is $\geq 33^{\circ} \mathrm{C}$, and a TND as the number of days when the minimum temperature at night is $\geq 25^{\circ} \mathrm{C}$. Furthermore, the July-August mean data were used because HWDs usually occur in July and August in Korea (Fig. 1b). In Korea, TNDs also mainly occur in July and August (not shown).

In this study, the East Asian summer monsoon (EASM) index (EASMI) derived by Li and Zeng (2002, 2003, 2005) was used. In addition, WNPSM and Indian summer monsoon indices (WNPSMI and ISM indices) provided by the Asia-Pacific data research center (APDRC) website of the University of Hawaii (http://apdrc.soest.hawaii. edu/projects/monsoon/seasonal-monidx.html) were used. Indian Rainfall (AIR) indices were provided by the Indian Institute of Tropical Meteorology (IITM) website (https:// www.tropmet.res.in/Data\%20Archival-51-Page).

The data from the Regional Specialized Meteorological Center (RSMC)-Tokyo Typhoon Center were used to analyze tropical cyclones (TCs). In addition, the National Center for Environmental Prediction/National Center for Atmospheric Research (NCEP/NCAR) Reanalysis dataset (Kalnay et al. 1996) was used to analyze large-scale environments and atmospheric circulation. Monthly global SST data used was obtained by Extended Reconstructed SST analysis (version 3) by the National Oceanic and Atmospheric Administration (NOAA) (Smith et al. 2008), and the precipitation data were obtained from the Global Precipitation Climatology Project (GPCP) version 2.3 (Adler et al. 2003). This study also used the $2 \mathrm{~m}$ air temperature $(\mathrm{T} 2 \mathrm{~m})$, which has a T62 Gaussian grid.

\subsection{Methodology}

A two-tailed Student's $t$ test was used to determine the significances of the results. Composite difference analysis was used to study the variation of the large-scale environments.

A TC was defined as a TC that developed in the WNP above a tropical depression (TD). Extratropical cyclones (ECs) were included in the study because ECs are transformed from TCs and have caused considerable casualties and property damage in the mid-latitude regions in East Asia.
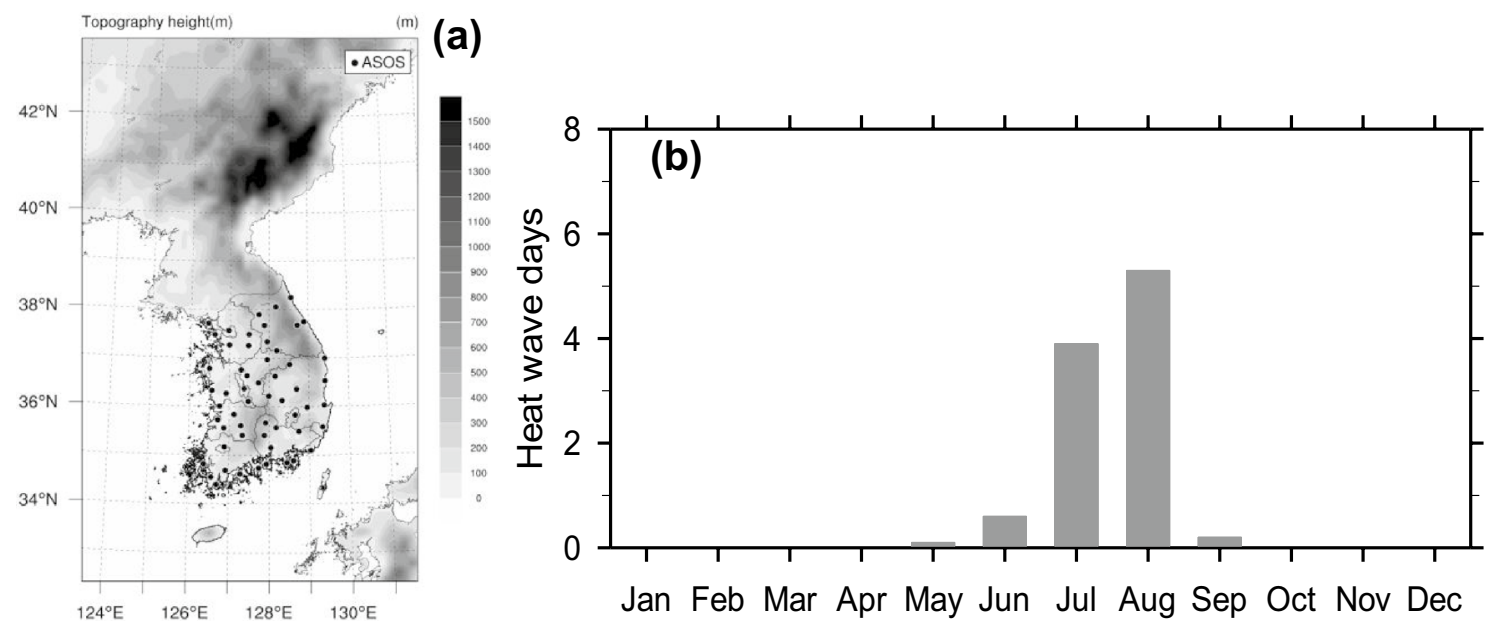

Fig. 1 a spatial distribution of weather observation stations in Korea and $\mathbf{b}$ monthly distribution of heatwave days (HWD) 


\section{Definition of South Asian high (SAH) index}

Figure 2a shows $200 \mathrm{hPa}$ geopotential heights averaged over 47 years (1973-2019). Here, SAH is defined as a region larger than $12,500 \mathrm{gpm}$. The SAH is zonally stretched from the Arabian Peninsula to southern China and is located between latitudes $20^{\circ}$ to $30^{\circ} \mathrm{N}$. In this study, SAH centers were defined as follows: A-area $\left(27.5^{\circ}-32.5^{\circ} \mathrm{N}, 55^{\circ}-75^{\circ} \mathrm{E}\right)$, B-area $\left(27.5^{\circ}-32.5^{\circ} \mathrm{N}, 85^{\circ}-105^{\circ} \mathrm{E}\right), \mathrm{C}$-area $\left(22.5^{\circ}-27.5^{\circ} \mathrm{N}\right.$, $\left.55^{\circ}-75^{\circ} \mathrm{E}\right)$, and $\mathrm{D}$-area $\left(22.5^{\circ}-27.5^{\circ} \mathrm{N}, 85^{\circ}-105^{\circ} \mathrm{E}\right)$. The differences between east (BD-area) and west (AC-area) areas, south (CD-area) and north (AB-area) areas, southwest (C-area) and northeast (B-area) areas, and northwest
(A-area) and southeast (D-area) areas were calculated using the averages of these four areas.

Table 1 Correlation between each displacement of South Asian high (SAH) and heat wave days (HWD) in Korea

\begin{tabular}{lllll}
\hline & \multicolumn{3}{l}{ Displacement of South Asian high (SAH) } \\
\cline { 2 - 5 } & A minus D & B minus C & AB minus & BD minus AC \\
& & & CD & \\
\hline $\begin{array}{l}\text { Heat wave } \\
\text { days } \\
\text { (HWD) }\end{array}$ & 0.62 & -0.04 & 0.51 & -0.40 \\
\hline
\end{tabular}

Fig. 2 a July-August (JA) climatological mean $200 \mathrm{hPa}$ geopotential height and time series of b South Asian high (SAH) index (A area minus $\mathrm{D}$ area in a) and HWD in Korea and c detrended SAH index and HWD in Korea. In a A, B, C, and D denote northwestern (NW), northeastern (NE), southwestern (SW), and southeastern areas of SAH
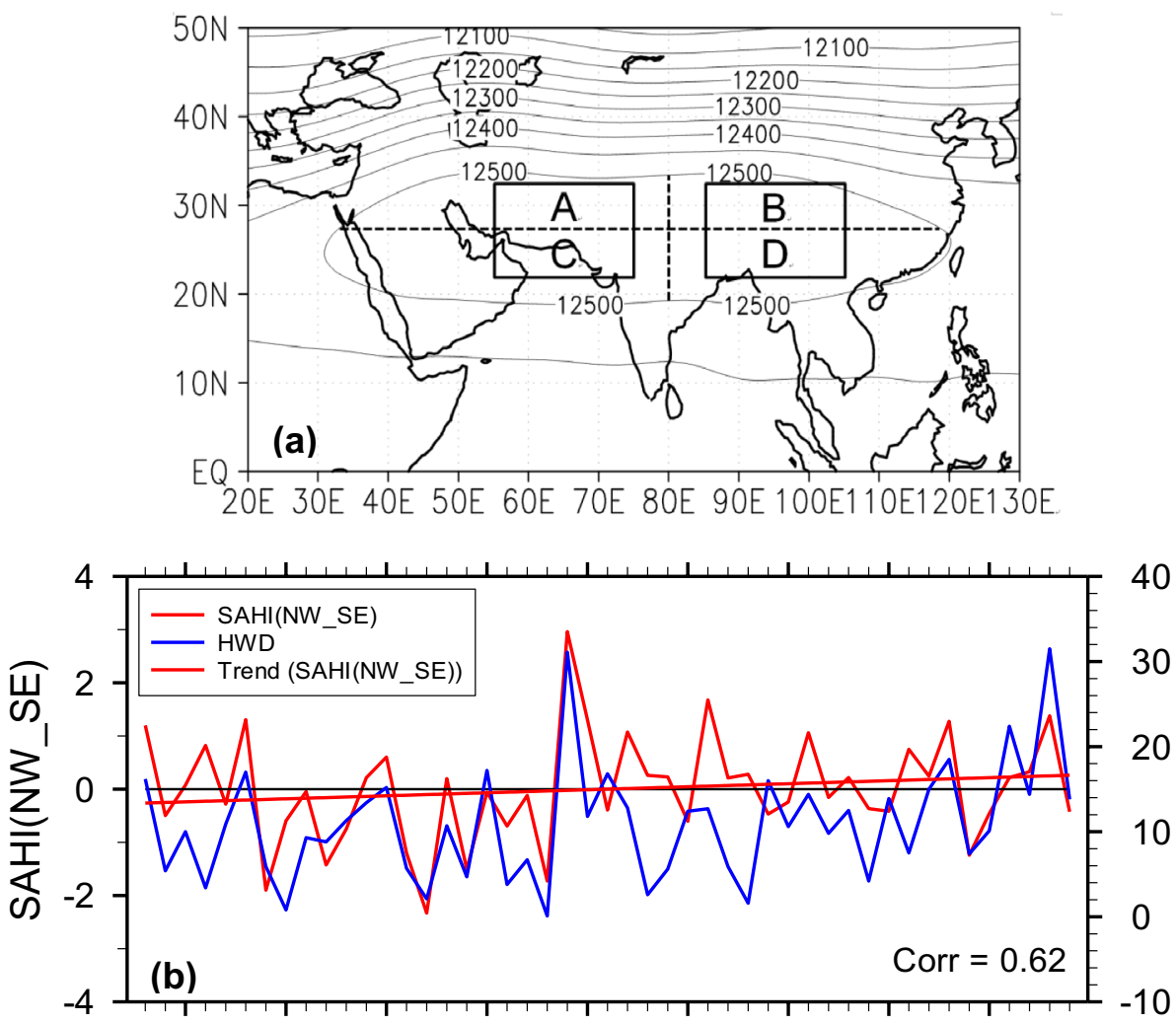

197519801985199019952000200520102015

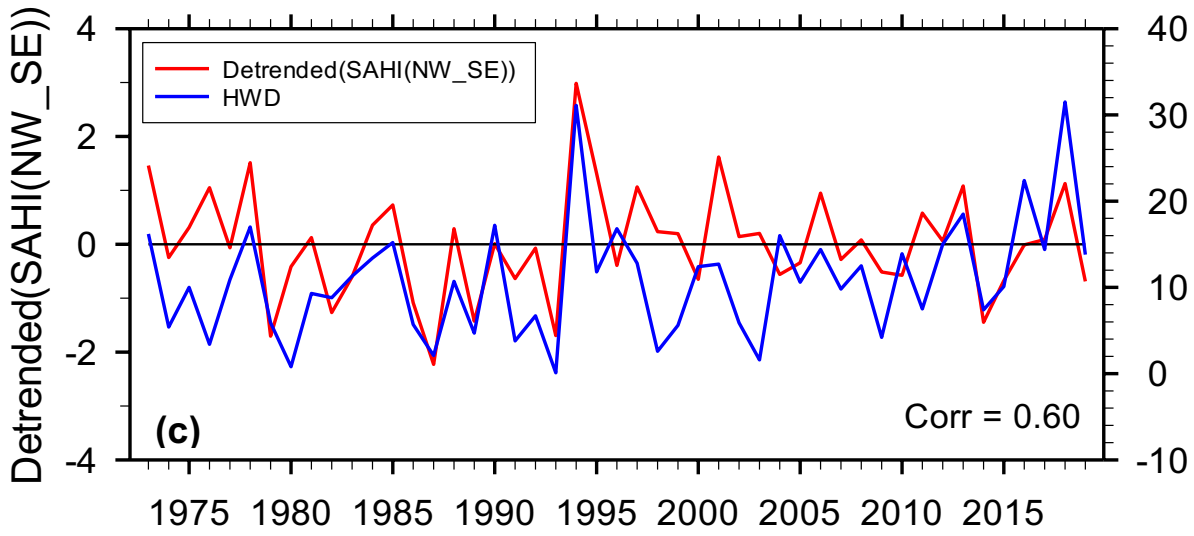


The correlations between the movements of SAH center in the east-west, south-north, southwest-northeast, and northwest-southeast directions and Korean HWDs were examined using these four sets of SAH values (Table 1). The strongest correlation with a positive correlation coefficient of 0.62 occurred when the SAH center moved in a northwest-southeast direction, and this correlation was significant at the $99 \%$ confidence level.

In addition, movements of the SAH center in a southnorth direction or an east-west direction exhibited correlations of 0.51 and -0.40 , respectively, and both correlations were significant at the $99 \%$ confidence level. As revealed by the correlation coefficients, more (less) HWDs correspond to northward (southward) and westward (eastward) shifts of the SAH, which may reflect the northwestward (southeastward) movement of the SAH. Therefore, the south-north and east-west shifts are in accordance with the movement in the northwest-southeast direction. Indeed, Wei et al. (2015) reported that the movement of the SAH in the northwest-southeast direction is a dominant mode for the horizontal shift of the SAH in the interannual timescale. On the other hand, the correlation was negative and non-significant when the SAH center moved in a southwest-northeast direction. Therefore, this study investigated the relationship between the movement of the SAH center in the southeast-northwest direction and HWDs in Korea, which had the strongest correlation. The SAH indices represent the movement of the SAH center in a northwest-southeast direction and were calculated as follows (Wei et al. 2012, 2014):

SAH index $=$ Z200(A) $)_{(27.5-32.5 N, 55-75 E)}-$ Z200(D) $)_{(22.5-27.5 N, 85-105 \mathrm{E})}$.

As shown in Fig. 2a, this index is defined as a normalized value of the area-mean $200 \mathrm{hPa}$ geopotential height difference between A-area and D-area. Thus, a positive (negative) index means the SAH center is strengthened in the northwest (southeast).

Figure $2 b$ shows the time series of the HWDs and the SAH indices in Korea calculated using the above equation. Both time series exhibited interannual and interdecadal variations, showed an obvious in-phase relationship, and were positively correlated at 0.62 , which was significant at the $99 \%$ confidence level. The SAH index tended to increase weakly. These results suggest that the HWDs increase in Korea when the SAH is strengthened in the northwest direction. However, the correlation is similar to that of the original correlation when the linear trend is removed from the SAH index time series. Thus, the linear trend was removed from the SAH index time series, and the correlation between the two variables was reanalyzed (Fig. 2c). A high positive correlation of 0.60 was obtained, which was similar to that of the original correlation. This correlation was also significant at the $99 \%$ confidence level. Therefore, this study selected 13 years with the highest SAH indices and removed the linear trend (hereinafter referred to as 'positive SAH years') and 13 years with the lowest SAH indices and removed the linear trend (hereinafter referred to as 'negative SAH index') (Table 2). These selected 26 years accounted for approximately $56 \%$ of the total analysis period. During the positive (negative) SAH years, the SAH center was strengthened in the northwest (southeast) directions. Among the positive SAH years, the HWDs were $<10$ days in two $(1976,2011)$, whereas, among negative SAH years, the HWDs were $\leq 10$ days in five years $(1983,2000,2010,2015$, and 2019). Consequently, the average HWD of the positive SAH years was 15.8 days, and the average HWD of the negative SAH years was 7.7 days. This difference of 8.1 days was significant at the 95\% confidence level. Next, this study analyzed the difference between the average of the positive SAH years and the average of the negative SAH years in the following section.

\section{Differences between positive and negative $S A H$ years}

\subsection{Spatiotemporal variations of SATs and precipitation in Korea}

During the positive SAH years, most areas, excluding the northeastern region of Korea, had SATs of $\geq 25{ }^{\circ} \mathrm{C}$ (left panel of Fig. 3a), whereas, during the negative SAH years, most regions had SATs of $\leq 24{ }^{\circ} \mathrm{C}$ (left panel of Fig. 3b).

Table 2 Statistics on HWD in Korea in positive and negative SAH years

\begin{tabular}{lllll}
\hline Positive SAH years & & & \multicolumn{2}{l}{ Negative SAH years } \\
\cline { 5 - 5 } Year & HWD & & Year & HWD \\
\hline 1973 & 16.2 & & 1979 & 5.9 \\
1976 & 3.4 & & 1982 & 8.8 \\
1978 & 17.0 & 1983 & 11.3 \\
1984 & 13.4 & 1986 & 5.7 \\
1985 & 15.2 & 1987 & 2.1 \\
1994 & 31.1 & 1989 & 4.7 \\
1995 & 11.8 & 1991 & 3.8 \\
1997 & 12.8 & 1993 & 0.1 \\
2001 & 12.7 & 2000 & 12.4 \\
2006 & 14.4 & 2010 & 13.9 \\
2011 & 7.5 & 2014 & 7.4 \\
2013 & 18.5 & 2015 & 10.1 \\
2018 & 31.5 & 2019 & 13.8 \\
Average & 15.8 & Average & 7.7 \\
\hline
\end{tabular}


(a) Positive SAH years

(b) Negative SAH years
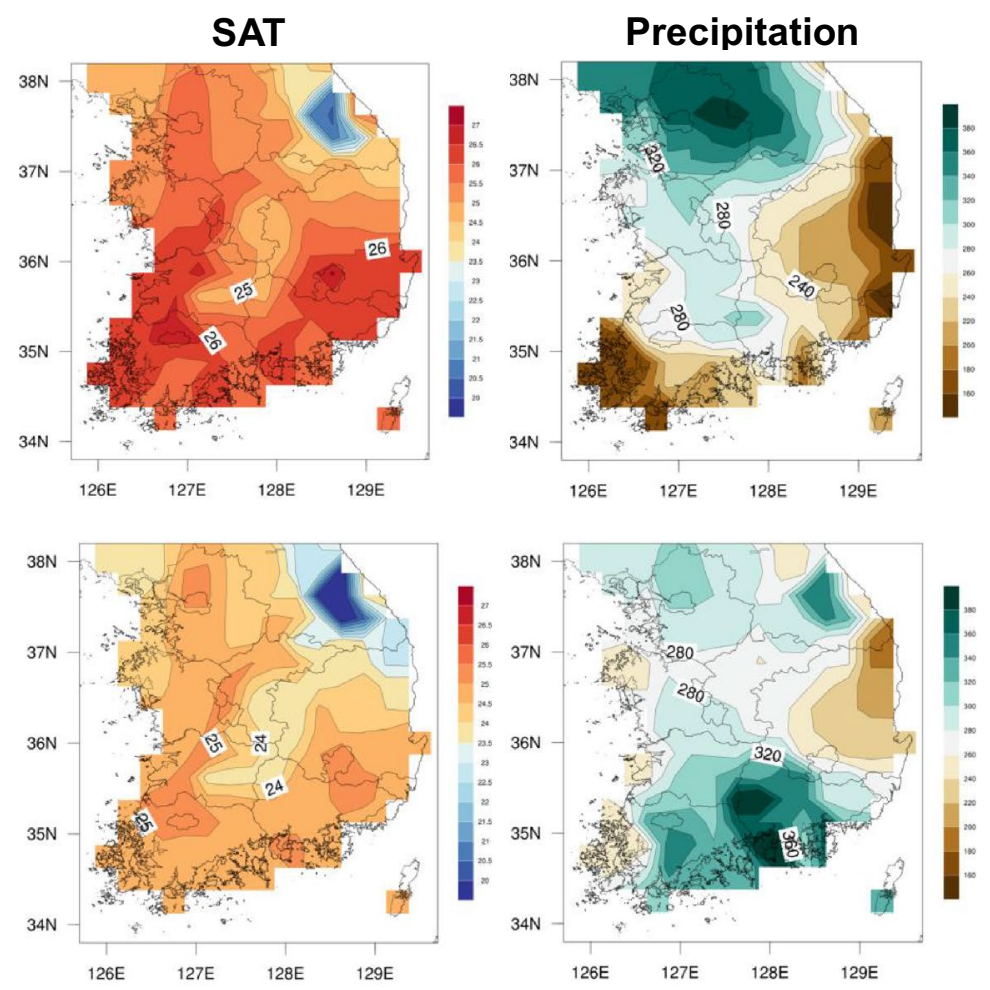

(c) Positive minus negative ${ }^{36 \mathrm{~N}}$
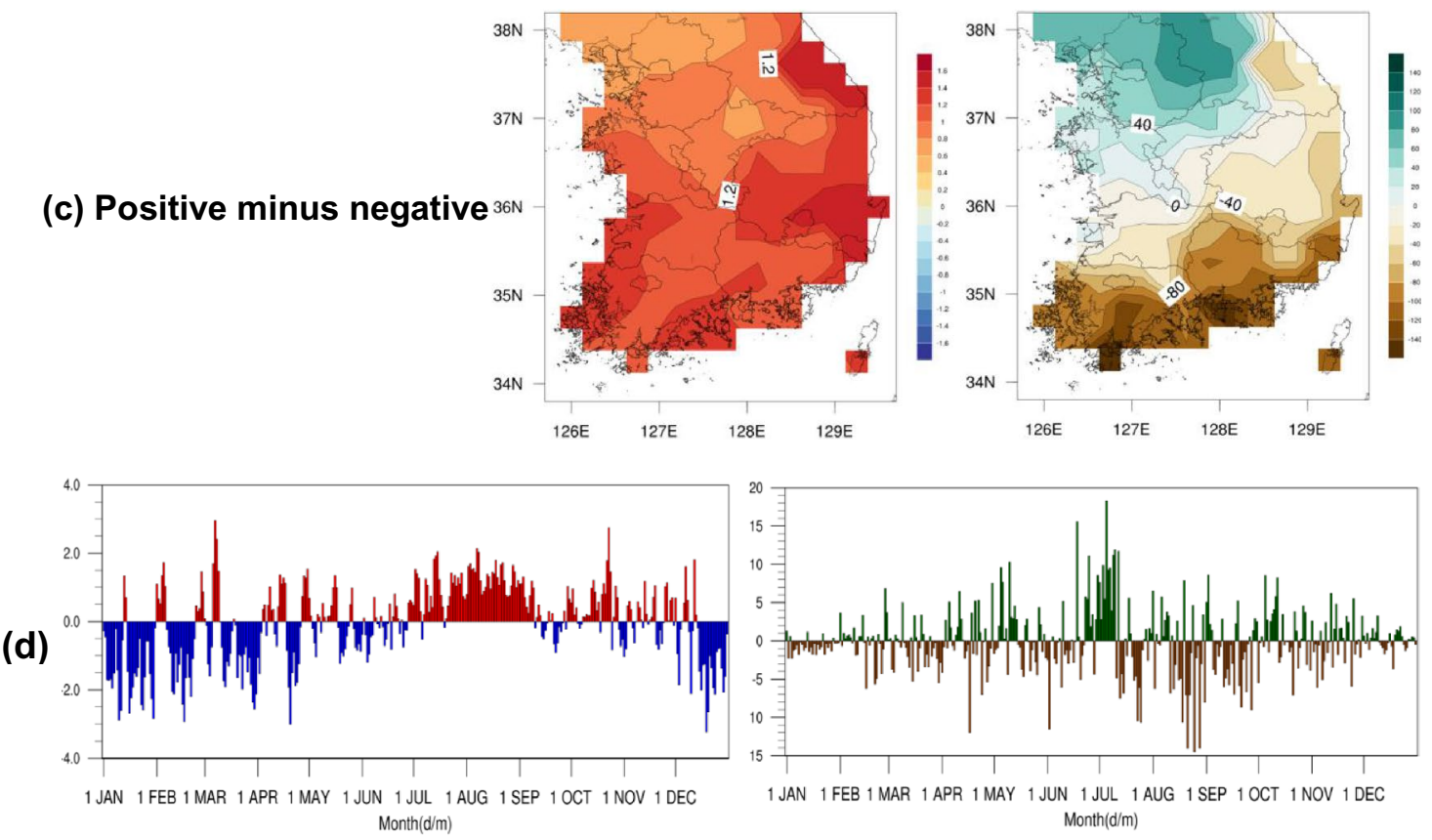

Fig. 3 Spatial distributions of surface air temperature (SAT; $\left.{ }^{\circ} \mathrm{C}\right)($ left panel) and precipitation (mm) (right panel) in a positive SAH years, b negative SAH years, and c positive minus negative SAH years in JA.

d Daily time series of SAT $\left({ }^{\circ} \mathrm{C}\right)$ (left panel) and precipitation (mm) (right panel) in positive minus negative $\mathrm{SAH}$ years

The differences between the two groups showed warm anomalies in most regions, even though the largest warm anomalies appeared along the coast (left panel of Fig. 3c). The time series of the difference in the daily SATs between the two groups showed a strong warm anomaly from July to early September, which suggested a high probability of a heatwave in Korea in the positive SAH years (left panel of Fig. 3d). During other seasons, the SAT values were higher in the negative SAH years. 
Regarding precipitation, the northern region of Korea experienced large precipitation of $>320 \mathrm{~mm}$ during the positive SAH years. In contrast, the southern and eastern coasts experienced precipitation of $\leq 240 \mathrm{~mm}$ (right panel of Fig. 3a). During the negative SAH years, large precipitation of $\geq 320 \mathrm{~mm}$ was distributed in the southern region (right panel Fig. 3b). As a result, the differences between the two groups showed a negative anomaly in the southern and eastern regions and a small positive anomaly in the northern region (right panel Fig. 3c). The time series of differences in daily precipitation between the two groups show strong negative anomalies from early July to September (right panel of Fig. 3d), which were associated with the appearance of a warm SAT anomaly. In other words, the probability of a heatwave was increased by low precipitation during this period.

\subsection{Large-scale environments}

The average $200 \mathrm{hPa}$ geopotential height was analyzed in the positive and negative SAH years to examine the spatial distributions of SAHs in these years (Fig. 4). During the positive $\mathrm{SAH}$ years, the $12,560 \mathrm{gpm}$ contour was located from Iran to northern India (Fig. 4a), but during the negative SAH years, it was distributed more broadly in the east-west direction from northeast of the Arabian Peninsula to the Tibetan Plateau (Fig. 4b). Thus, during the positive $\mathrm{SAH}$ years, the $\mathrm{SAH}$ center was located at $30^{\circ} \mathrm{N}, 58^{\circ} \mathrm{E}$, whereas during negative $\mathrm{SAH}$ years, it was located at $27^{\circ} \mathrm{N}, 93^{\circ} \mathrm{E}$. This means that during the positive SAH years, the SAH was located more to the northwest.

The spatial distribution of regression of $2 \mathrm{~m}$ air temperature (T2m) against the SAH indices were also examined (Fig. 5a). Positive values were observed from the central region of China to Korea and for all of Japan. Furthermore, positive values also appeared in the Central Asia and North Pacific regions at $40^{\circ}-50^{\circ} \mathrm{N}$, which means that $\mathrm{T} 2 \mathrm{~m}$
Fig. 4 JA mean $200 \mathrm{hPa}$ geopotential height $\mathbf{a}$ in positive SAH years and $\mathbf{b}$ in negative $\mathrm{SAH}$ years. The red dots denote the centers of SAH (a) Positive SAH years

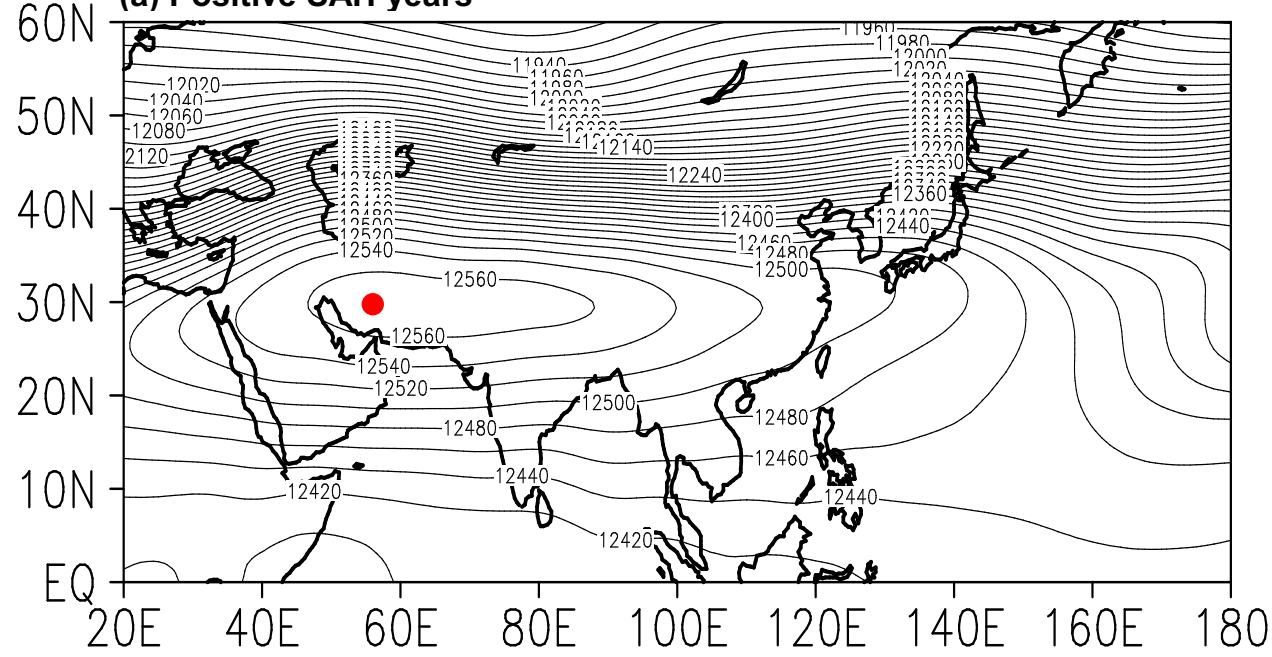

(b) Negative SAH years

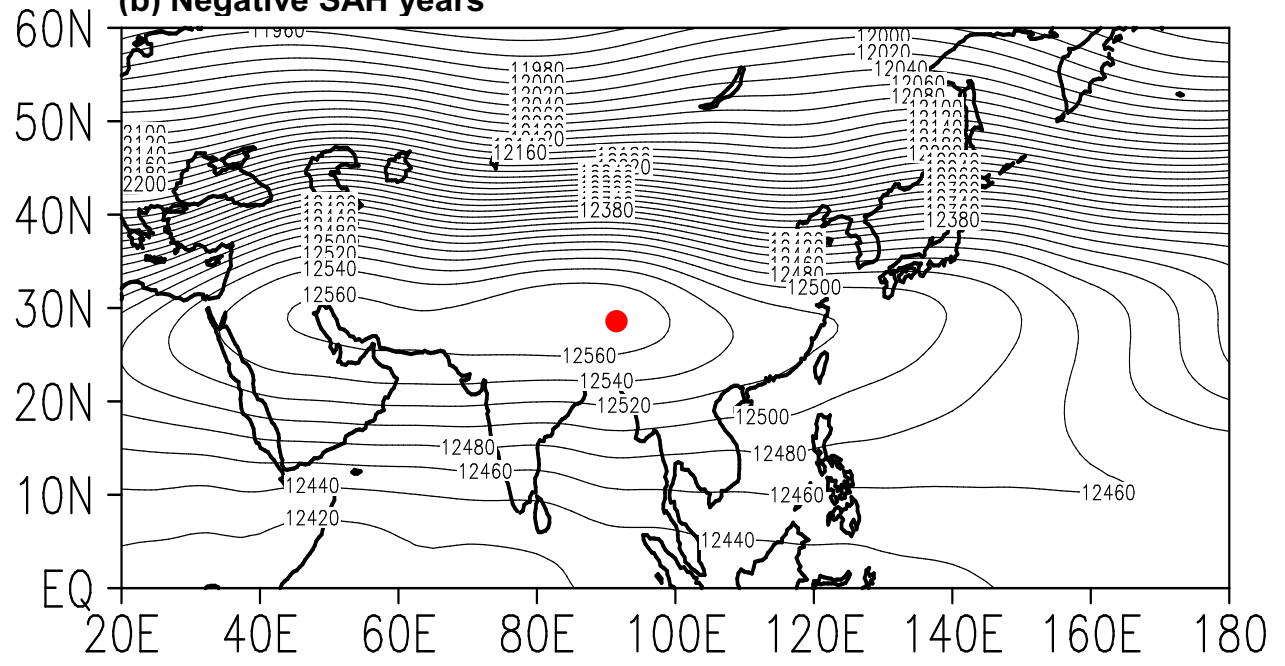


Fig. 5 a regression map of $2 \mathrm{~m}$ air temperature (T2m) against SAH index in JA and time series of SAH index and $\mathrm{T} 2 \mathrm{~m}$ in b Northeast Asia (A area: $\left.30^{\circ}-40^{\circ} \mathrm{N}, 120^{\circ}-140^{\circ} \mathrm{E}\right)$ and $\mathbf{c}$ South China (B area: $20^{\circ}-25^{\circ} \mathrm{N}, 100^{\circ}-120^{\circ} \mathrm{E}$ )

\section{(a) Reg. T2m against SAH index}
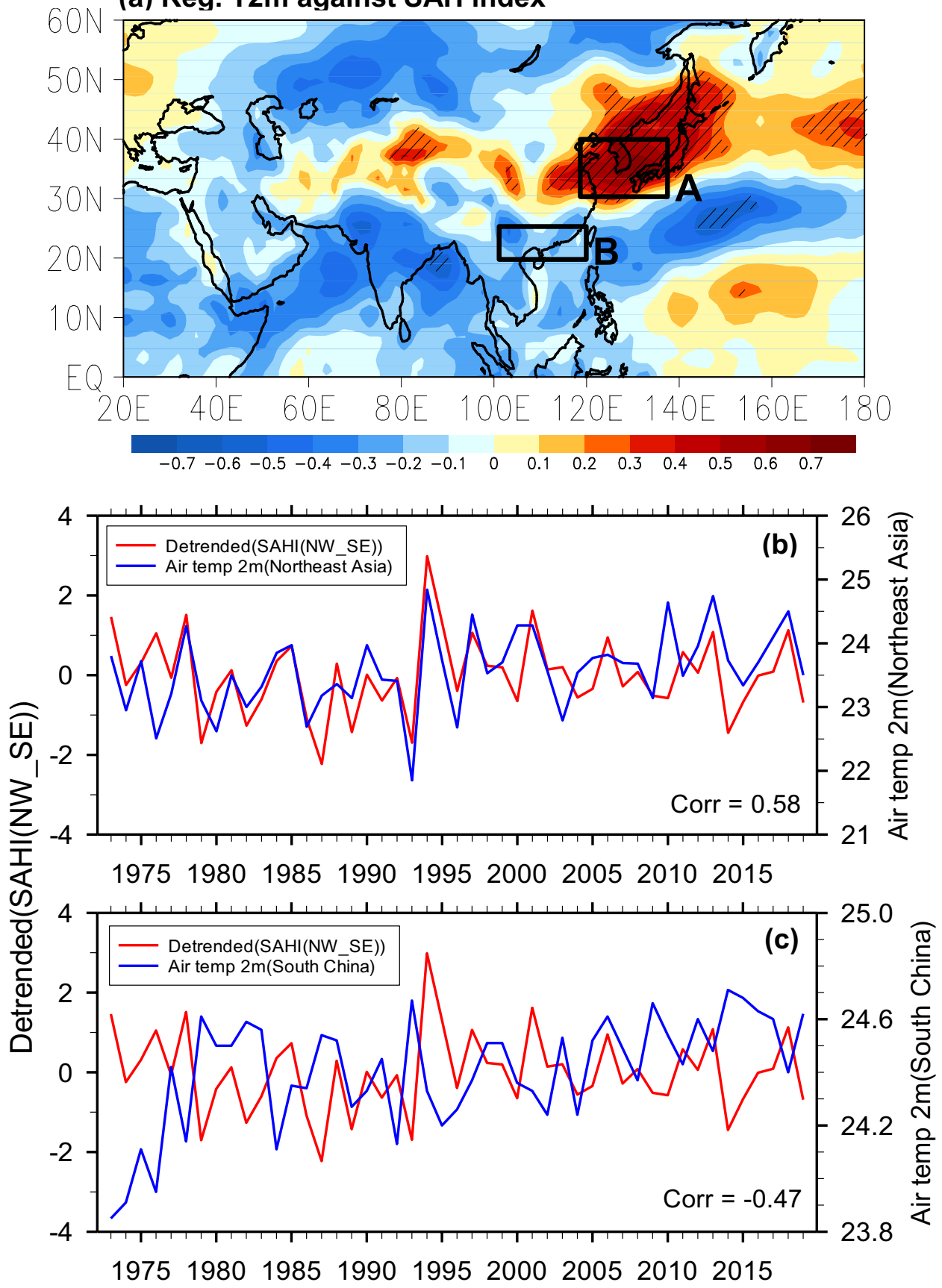

increased in this region when the SAH is strengthened in the northwest. Therefore, when the SAH is strengthened in the northwest region, there is a possibility that a heatwave could be generated in Korea, central China, and Japan. Thus, the East Asian region was divided into northeast Asia $\left(30^{\circ}-40^{\circ} \mathrm{N}, 120^{\circ}-130^{\circ} \mathrm{E}\right)$ and South China $\left(20^{\circ}-25^{\circ} \mathrm{N}\right.$, $100^{\circ}-120^{\circ} \mathrm{E}$ ) and the correlation between $\mathrm{T} 2 \mathrm{~m}$ averaged for each region and SAH indices with the linear trend removed was analyzed. The SAH indices and the time series of T2m averaged for northeast Asia showed a clear in-phase relationship (Fig. 5b) with a positive correlation of 0.58 , which was significant at the $99 \%$ confidence level. This means that the $\mathrm{T} 2 \mathrm{~m}$ increased (decreased) in northeast Asia when the SAH strengthened in a northwest (southeast) direction. A clear out-of-phase relationship was observed between the SAH indices and the T2m time series averaged for South China (Fig. 5c) with a significant negative correlation of -0.47 , which was significant at the $99 \%$ confidence level. This means that the T2m decreased (increased) in South China when the SAH strengthened to the northwest (southeast).

The differences in specific humidity between the two groups were then analyzed. The $850 \mathrm{hPa}$ specific humidity 
(a) $850 \mathrm{hPa}$ specific humidity

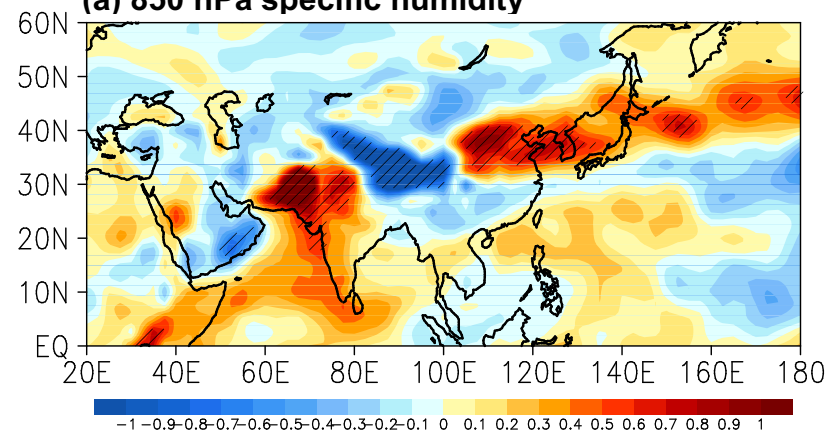

(b) $500 \mathrm{hPa}$ specific humidity

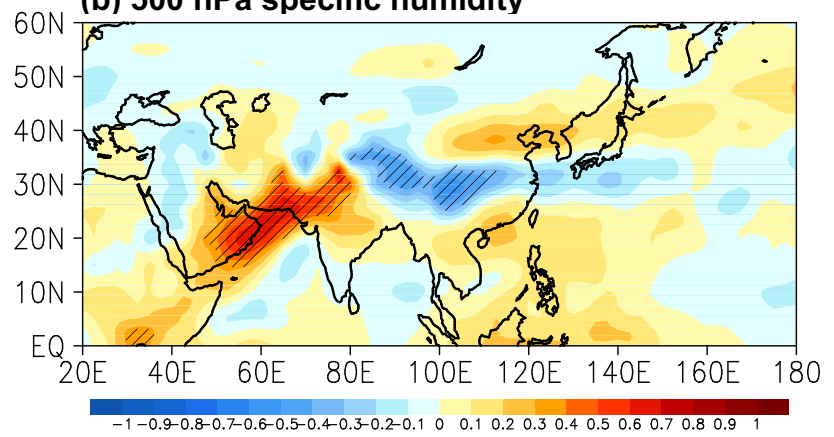

(c) $300 \mathrm{hPa}$ specific humidity

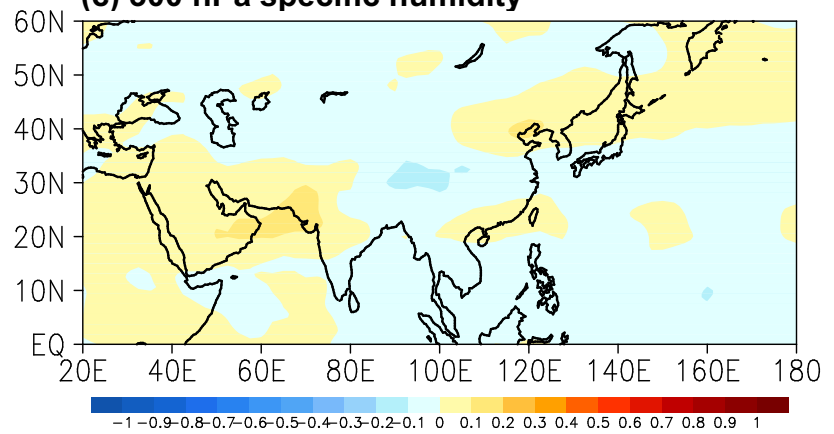

Fig. 6 Composite differences in a 850, b 500, and c $300 \mathrm{hPa}$ specific humidity between positive SAH years and negative SAH years in JA. The hatched areas are significant at the $95 \%$ confidence level

exhibited a spatial distribution with a wave train shape, i.e., a negative anomaly in the Arabian Peninsula, a positive anomaly in the northwestern region of India, a negative anomaly in west China, and a positive anomaly from central China to Korea and Japan (Fig. 6a). This spatial distribution weakened at higher altitudes (Fig. 6b, c). During the positive SAH years, the discomfort index might be expected to be high because the T2m and specific humidity were high in northeast Asia. The discomfort index is defined as (dry-bulb temperature + wet-bulb temperature $) \times 0.72+40.6$.

The difference between the composites in the vertical meridional circulation averaged along $120^{\circ}-130^{\circ} \mathrm{E}$, which includes Korea, was also analyzed (Fig. 7a). Downward flows formed in $25^{\circ}-35^{\circ} \mathrm{N}$ and were distributed in

\section{(a) Vertical meridional circulation}

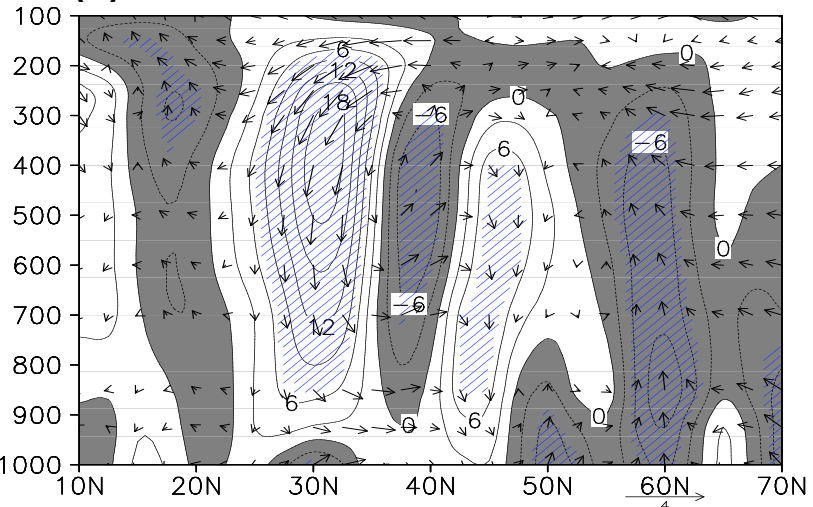

(b) Air temperature

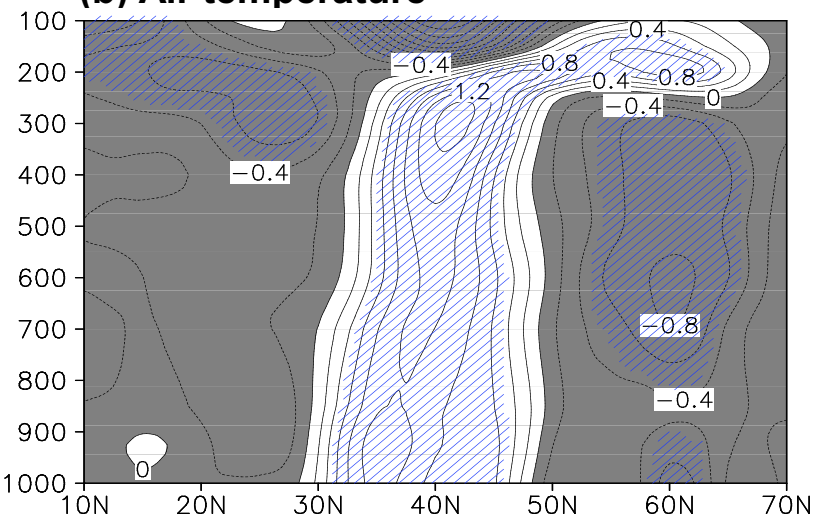

(c) Specific humidity

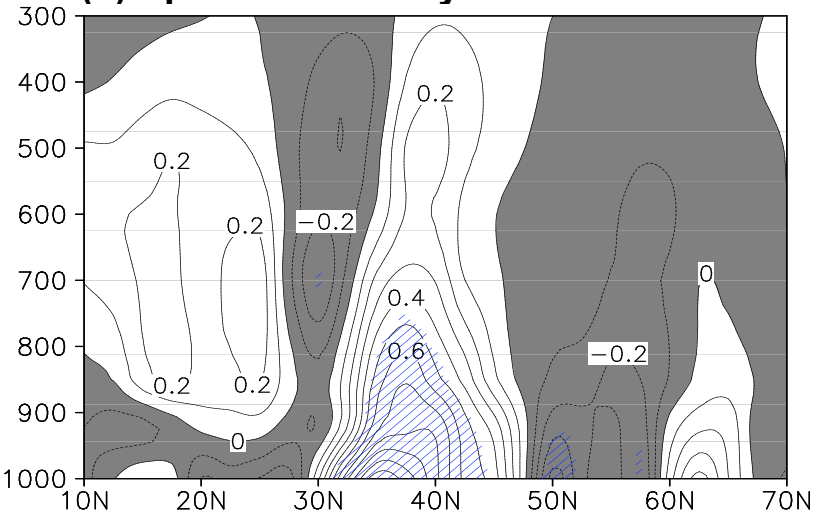

Fig. 7 Composite differences of latitude-pressure cross-section of a vertical velocity (contours) and meridional circulations (vectors), b air temperature, and c specific humidity averaged along $120^{\circ}-130^{\circ} \mathrm{E}$ between the positive and negative SAT years in JA. The values of the vertical velocity are multiplied by -100 . The dashed areas are significant at the $95 \%$ confidence level, and shaded areas denote the negative values. Contour intervals are $3^{-2} \mathrm{hPa} \mathrm{s}^{-1}, 0.2^{\circ} \mathrm{C}$, and $0.1 \mathrm{~g} \mathrm{~kg}^{-1}$ for vertical velocity, air temperature, and specific humidity, respectively

$30^{\circ}-35^{\circ} \mathrm{N}$, which also contains the southern part of South Korea. Furthermore, positive anomalies of air temperature and specific humidity were distributed in $30^{\circ}-50^{\circ} \mathrm{N}$ with centers located in $30^{\circ}-40^{\circ} \mathrm{N}$ (Fig. $7 \mathrm{~b}, \mathrm{c}$ ). As mentioned 
above, warm anomalies formed in all layers of the troposphere in Korea because of strengthened anomalous downward flows in all troposphere layers. In addition, due to the positive strengthening of specific humidity in all layers of the troposphere, an environment was formed that favored a high discomfort index in Korea.

WNPSH is also associated with heatwaves. Hence, this study examined the spatial distributions of SAH and WNPSH in the two groups (Fig. 8). During positive SAH years, the SAH was located in $20^{\circ}-40^{\circ} \mathrm{N}$ in a south-north direction and extended from eastern Japanese waters toward the east in the zonal direction (Fig. 8a). The WNPSH extended to the Shandong Peninsula in the northwest direction, and as a result, the two high-pressure systems overlapped in Korea. This is consistent with the above result that during the positive SAH years, the anomalous high
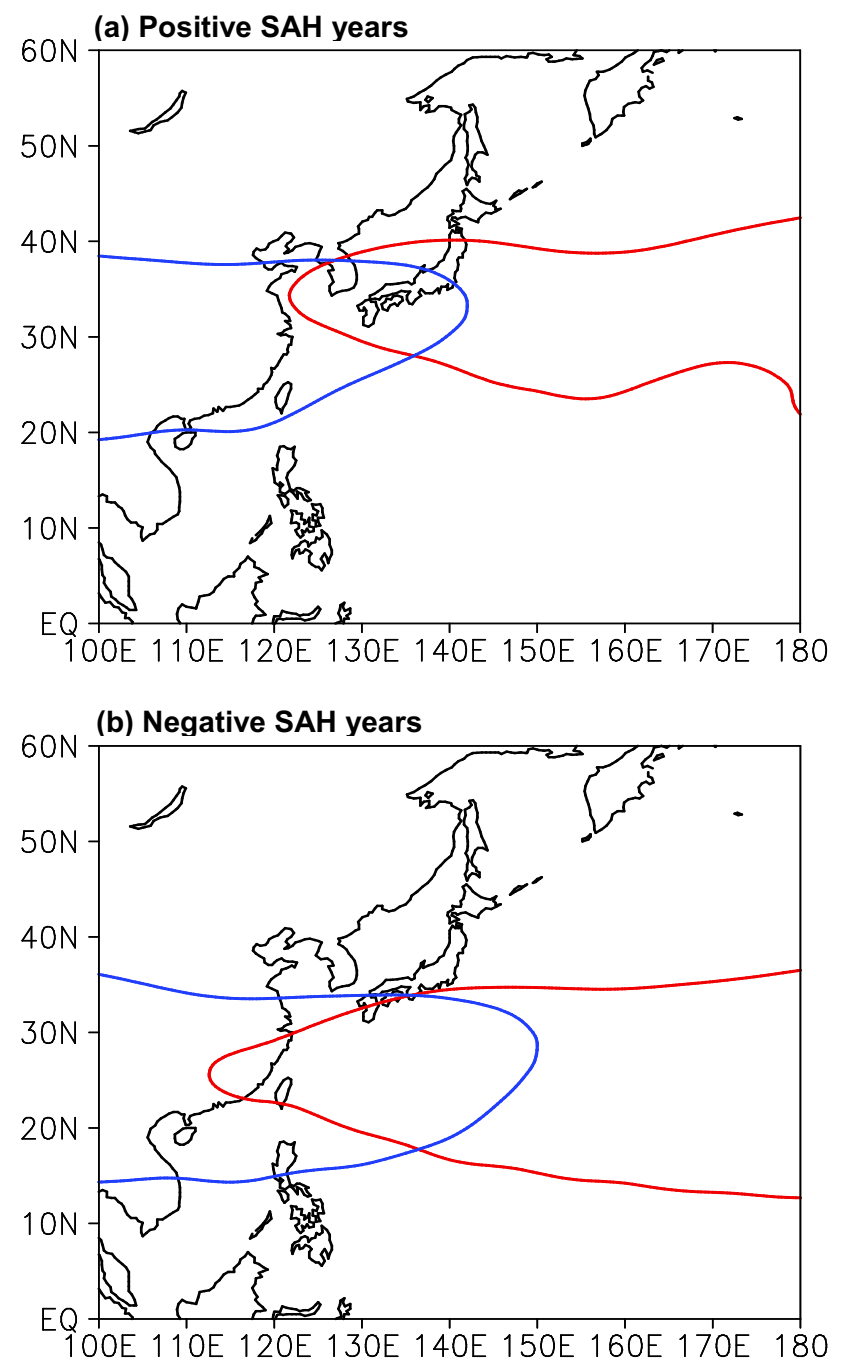

Fig. 8 Spatial distributions of western North Pacific subtropical high (WNPSH; 5,870 gpm contour) and SAH (12,480 gpm contour) in JA. Red and blue lines indicate the WNPSHs and SAHs in the positive $\mathrm{SAH}$ years and negative SAH years, respectively strengthened in all layers of the Korean troposphere. Hence, during positive SAH years, the HWD can increase more in Korea, whereas during the negative SAH years, the SAH develops more to the southeast, and the WNPSH extended to the southwest (Fig. 8b), which results in an overlap of the two high-pressure systems in southern China. This means that the air temperature is likely to increase in South China during the negative $\mathrm{SAH}$ years, which is consistent with the above result showing that the SAH index and T2m are negatively correlated in southern China.

\subsection{Tropical cyclone activity}

Frequent TCs can temporarily lower heatwave frequencies. Therefore, this study investigated the differences in TC passage frequencies (TCPFs) between the two groups (Fig. 9). During the positive SAH years, TCs show a strong tendency to move from the northeastern region of the Philippines to central China and then to northern China. As found above, this occurs because the WNPSH develops in the northwestern direction to the Shandong Peninsula during the positive SAH years, whereas during negative SAH years, TCs mainly move from the far eastern sea of the Philippines to the East China Sea (ECS) and then to Korea and Japan, or to the west toward the Indochina Peninsula. As shown above, because the WNPSH develops in the southwest direction to South China during the negative SAH years, TCs move toward the Indochina Peninsula, or even if they move to the mid-latitude region of East Asia, they do not move more to the west but move to the northeast along the mid-latitude westerlies. Hence,

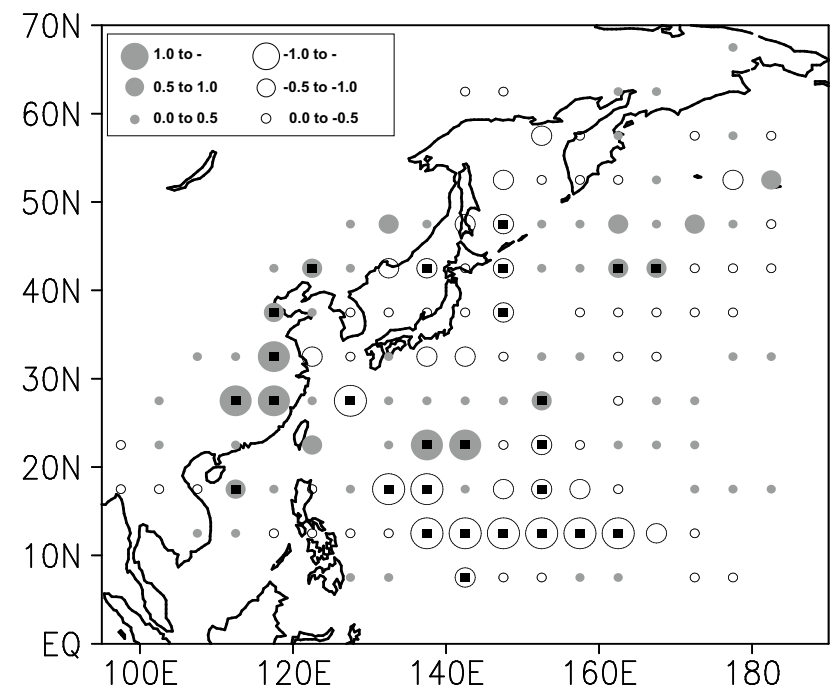

Fig. 9 Composite difference in the TC passage frequency (TCPF) between positive and negative SAH years in JA. The small squares inside the circles indicate that the differences are significant at the $95 \%$ confidence level 
during positive SAH years, HWDs can increase in Korea due to the low TC frequencies. The number of TCs affecting South Korea in the positive and negative SAH years are 13TCs and 19TCs, respectively.

\subsection{The relationship between HWDs in Korea and Circumglobal Teleconnection}

Figure 10 shows the results of an analysis of the differences in the 850,500 , and $200 \mathrm{hPa}$ stream flows and geopotential heights in the two groups. In general, during positive

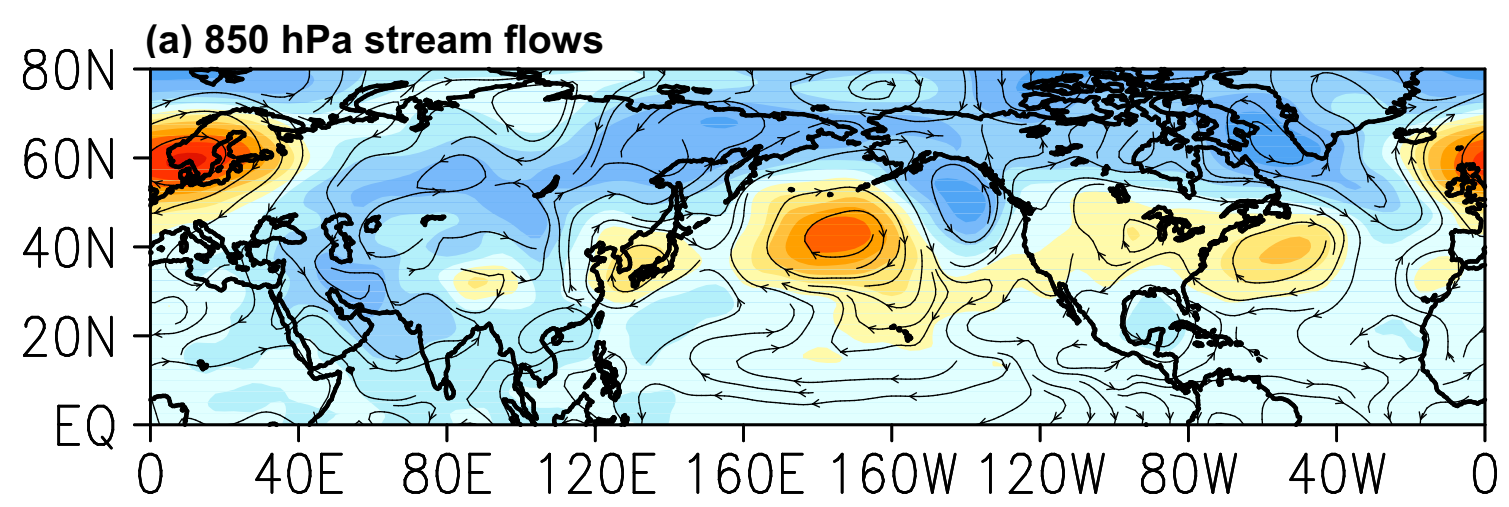

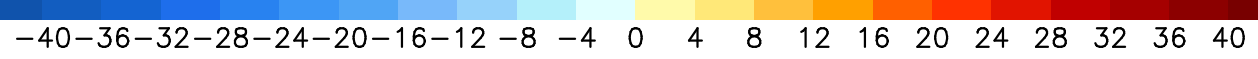

(b) $500 \mathrm{hPa}$ stream flows

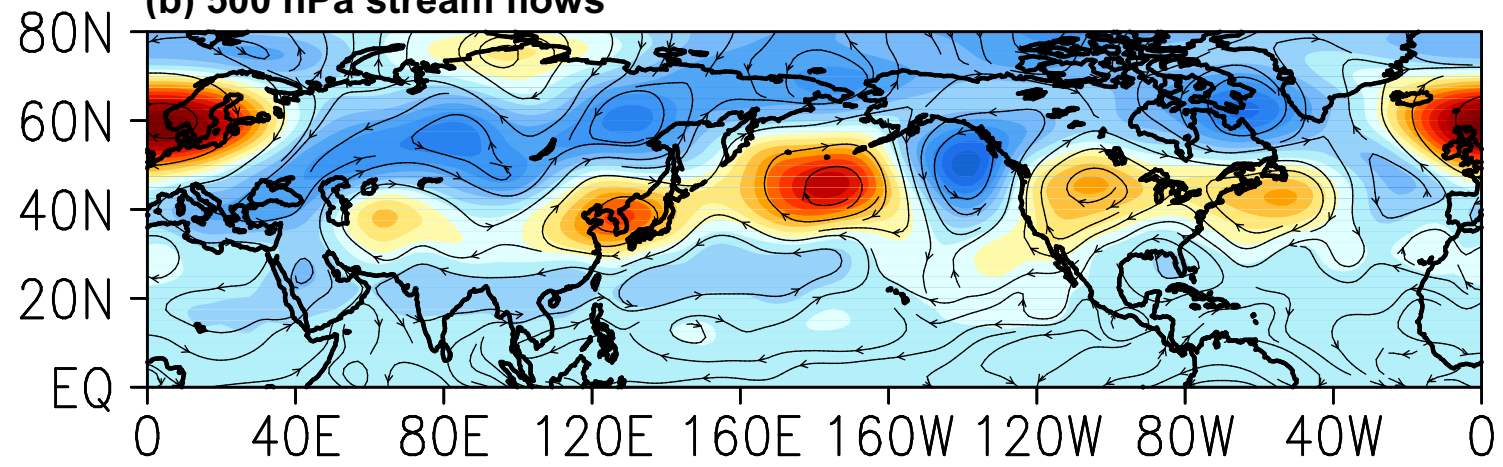

$-40-36-32-28-24-20-16-12-8 \quad-4 \quad 0 \quad 4 \quad 8 \quad 12 \quad 16 \quad 20 \quad 24 \quad 28 \quad 32 \quad 36 \quad 40$

(c) $200 \mathrm{hPa}$ stream flows

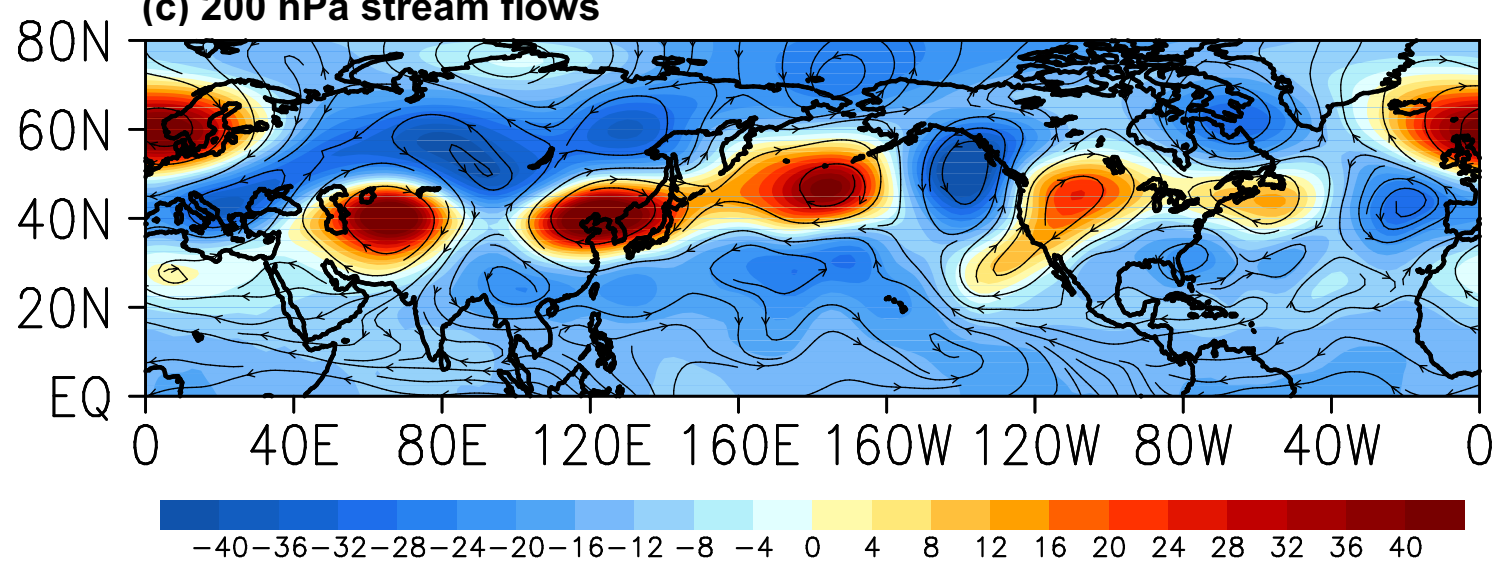

Fig. 10 Composite differences in a $850 \mathrm{hPa}, \mathbf{b} 500 \mathrm{hPa}$, and c $200 \mathrm{hPa}$ stream flow and geopotential height between the positive and negative SAH years in JA 
(a) Positive SAH years minus Clim

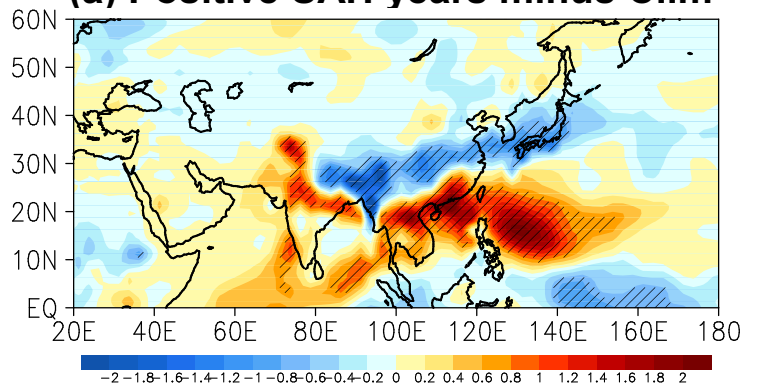

(b) Negative SAH years minus Clim

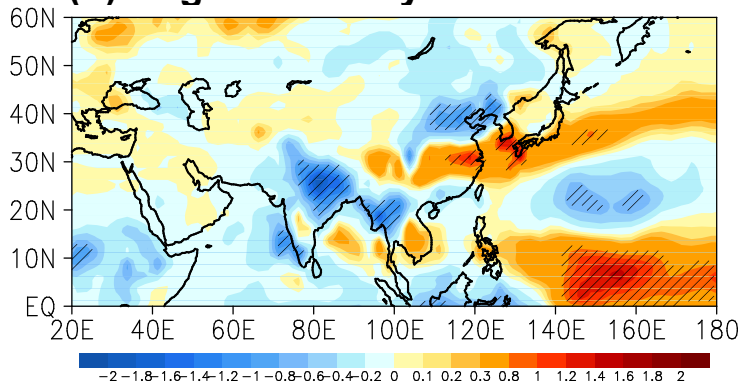

(c) Positive minus negative SAH years

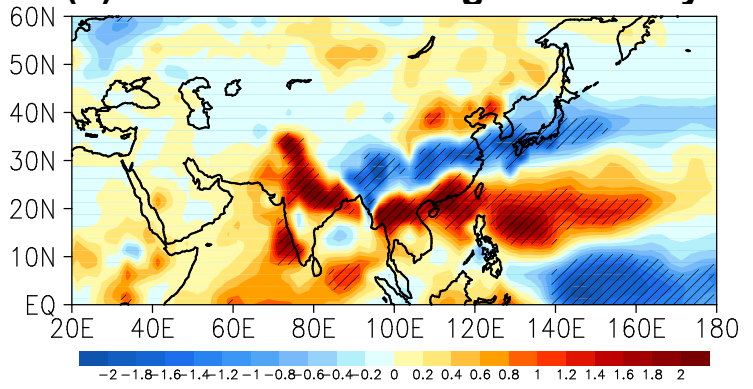

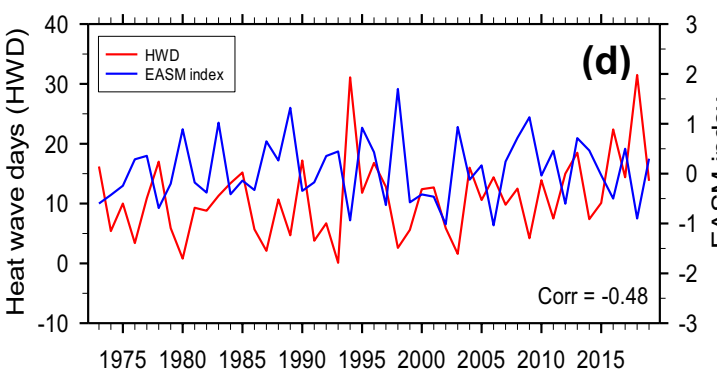

197519801985199019952000200520102015

Fig. 11 Differences in precipitation a between the positive SAH years and climatology, b between negative SAH years and climatology, and $\mathbf{c}$ between the positive SAH years and negative SAH years in JA. Time series of $\mathbf{d}$ HWD in Korea and East Asian summer monsoon

SAH years, anomalous anticyclones developed in Korea, the North Pacific, North America, Western Europe, and the Iranian Plateau. These anticyclones displayed the wavenumber-5 pattern and a barotropic vertical structure, becoming more distinct at higher altitudes. This spatial distribution is similar to the circumglobal teleconnection (CGT) pattern

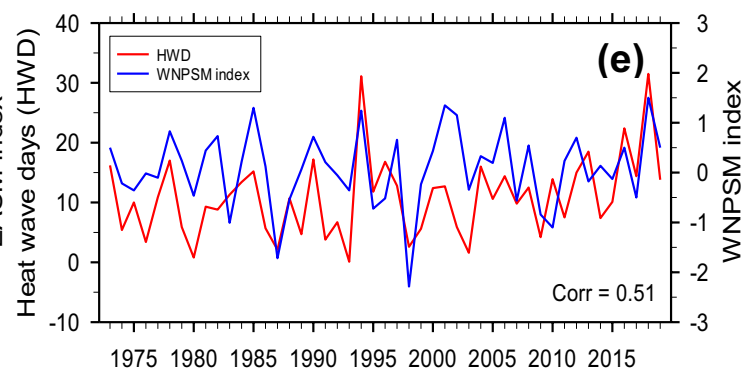

(EASM) index and $\mathbf{c}$ HWD in Korea and western North Pacific summer monsoon (WNPSM) index. Here, climatology indicates average from 1973 to 2019 in JA. In a-c, dashed areas are significant at the 95\% confidence level

discovered by Ding and Wang $(2005,2011)$, who suggested that maintenance of the CGT depends on the interaction between the CGT circulation and the ISM, which has a major influence on the mid-latitude atmosphere. Zhou et al. (2020) suggested that the maintenance of the CGT not only depends on the interaction between the CGT circulation and 
the ISM but also on the effects of EASM rainfall. A strengthened ISM forms an upper-level anomalous anticyclone in the northwestern region of India and generates continuous downstream cells along the waveguide through Rossby wave dispersion.

Thus, the ISM has a major effect on the CGT pattern. Accordingly, this study analyzed differences in precipitation between the two groups (Fig. 11). During the positive SAH years, compared to climatology (meaning averages for July and August for 1973-2019), a negative anomaly was formed from the southwest to the northeast from the northeastern region of India to Central China and then to Korea and Japan (Fig. 11a). On the other hand, a positive anomaly was formed in the Indochina Peninsula, the South China Sea (SCS), and the eastern region of the Philippines. The spatial distribution of the difference between the negative SAH years and climatology revealed a different pattern to that shown in Fig. 11a (Fig. 11b). The pattern correlation between the two spatial distributions was 0.88 . The spatial distribution of Fig. 11a can be seen more clearly in the spatial distribution of the difference between the positive and negative SAH years (Fig. 11c) and show that in Korea, decreased precipitation can increase the HWDs. In contrast, the Indian subcontinent showed a positive anomaly. During the positive SAH years, the negative anomaly of precipitation formed from Central China to Korea and Japan might mean a weakening of the EASM, whereas a positive anomaly of precipitation formed in the eastern region of the Philippines might be associated with a strengthening of the WNPSM. Therefore, this study analyzed the time series for HWDs in Korea and for the EASM and WNPSM indices (Fig. 11d, e). An obvious out-of-phase relationship was observed between the HWDs and EASM indices (Fig. 11d), but a clear in-phase relationship was observed between the HWDs and WNPSM indices (Fig. 11e). Consequently, the correlation between the HWDs and EASM indices was significant and negative (correlation - 0.48), and that between HWDs and WNPSM indices was significant and positive (correlation - 0.51) at the $99 \%$ confidence level. This means that in Korea, an increase (decrease) in HWDs was associated with weakening (strengthening) of the EASM and strengthening (weakening) of the WNPSM.

According to Ding and Wang $(2005 ; 2011)$, the effects of diabatic heating due to ISM precipitation maintain a center of action in the northwestern region of India. Therefore, the CGT index was defined as the $200 \mathrm{hPa}$ geopotential height averaged for the northwestern region of India $\left(35^{\circ}-50^{\circ} \mathrm{N}\right.$, $60^{\circ}-70^{\circ} \mathrm{E}$ ), and the correlation between the SAH and CGT indices was then analyzed (Fig. 12a). The time series of these two indices represented the interannual and interdecadal variations and showed a strong in-phase tendency and a positive correlation of 0.51 , which was significant at the 99\% confidence level. This suggests that the CGT pattern is developed (weakened) when the SAH is strengthened in the northwest (southeast). Therefore, the time series of HWDs in Korea and CGT, ISM, and all Indian rainfall (AIR) indices were analyzed (Fig. 12b-d). The CGT, ISM, and AIR indices all showed in-phase relationships with HWDs in Korea with significant positive correlations of $0.60,0.53$, and 0.51 at the $99 \%$ confidence level, respectively. This means that the HWDs increase (decrease) in Korea when the effect of the diabatic heating by ISM precipitation is strengthened (weakened) and that CGT, ISM, and AIR are strengthened (weakened).

The correlation between the HWDs in Korea and T2m was also analyzed because the diabetic heating effect of ISM precipitation maintains a center of action located at the northwest of India (Fig. 13a). In general, the correlations showed a similar pattern to the spatial distribution of the regression of $\mathrm{T} 2 \mathrm{~m}$ against the SAH index analyzed above. The pattern correlation between the two spatial distributions exhibited a positive correlation of 0.72 , which occurred because the HWDs in Korea and the SAH indices showed the strongest positive correlation (0.62) in northeast Asia. Furthermore, a positive correlation was also observed in the northwestern region of India. Therefore, the time series of HWDs in Korea and the T2m averaged for the northwestern region of India (area-A in Fig. $13 \mathrm{a} ; 30^{\circ}-40^{\circ} \mathrm{N}, 70^{\circ}-80^{\circ} \mathrm{E}$ ) were analyzed (Fig. 13b). These two variables showed a strong increasing trend and a distinct in-phase relationship, and thus, a significant positive correlation of 0.48 at the 99\% confidence level. This means that the HWDs in Korea are strongly correlated with the ISM variation and resulting CGT patterns.

\subsection{Relationships between the TNDs and PDSIs in Korea and SAH and CGT}

The relationships between the time series of TNDs in Korea and SAH and CGT indices were examined (Fig. 14a, b). The time series of the TNDs and SAH indices showed an increasing trend, particularly after 2010 (Fig. 14a) and a strong in-phase tendency, which resulted in a significant positive correlation of 0.60 at the $99 \%$ confidence level. The TNDs and CGT indices also showed a distinct in-phase relationship (Fig. 14b), resulting in a positive correlation of 0.54 at the 99\% confidence level, which suggests that, like HWDs, the TNDs are also strongly correlated with the ISM variations and resulting CGT patterns.

The higher the frequency of heatwaves, the less precipitation and the worse droughts can develop. Therefore, this study examined relationships between the time series of PDSI in Korea and SAH and CGT indices (Fig. 14c, d). The PDSI time series and SAH indices showed a trend of worsening drought, particularly after 2010 (Fig. 14c) and a distinct out-of-phase relationship, which resulted in a 

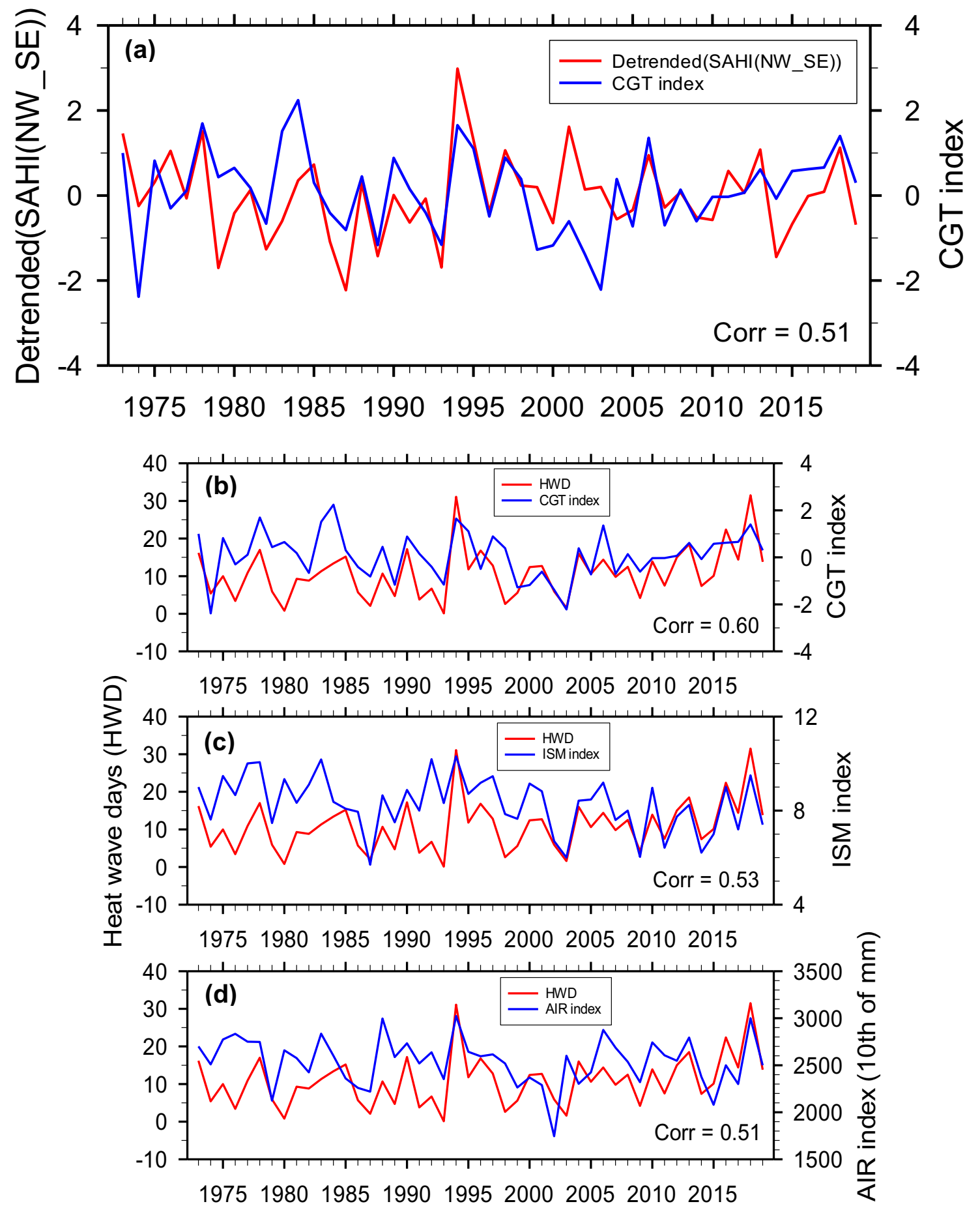

Fig. 12 Time series of a SAH index and circumglobal teleconnection (CGT) index, b HWD in Korea and CGT index, $\mathbf{c}$ HWD in Korea and Indian summer monsoon (ISM) index, and $\mathbf{d}$ HWD in Korea and all India rainfall (AIR) index in JA

significant negative correlation of -0.43 at the $99 \%$ confidence level. Furthermore, the correlation between PDSI and CGT indices also showed a distinct out-of-phase relationship (Fig. 14d) and a negative correlation of -0.41 at the $99 \%$ confidence level. These results suggested that the HWDs, TNDs, and PDSIs were strongly correlated with the
ISM variations and resulting CGT patterns. Indeed, both the northwest-southeast movement of the SAH and the maintenance of the CGT depend on both the ISM and the East Asian summer monsoon (EASM) (Wei et al. 2015). Previous studies have shown that the ISM, EASM, and SAH are affected by external forcing. For example, the land surface 
Fig. 13 a Correlation map between HWD in Korea and $\mathrm{T} 2 \mathrm{~m}$ in JA. b Time series of HWD in Korea and T2m averaged over area $\mathrm{A}\left(30^{\circ}-40^{\circ} \mathrm{N}\right.$, $70^{\circ}-80^{\circ} \mathrm{E}$ ) in a. In a, dashed areas are significant at the $95 \%$ confidence level (a) Correlation between HWD in Korea and T2m

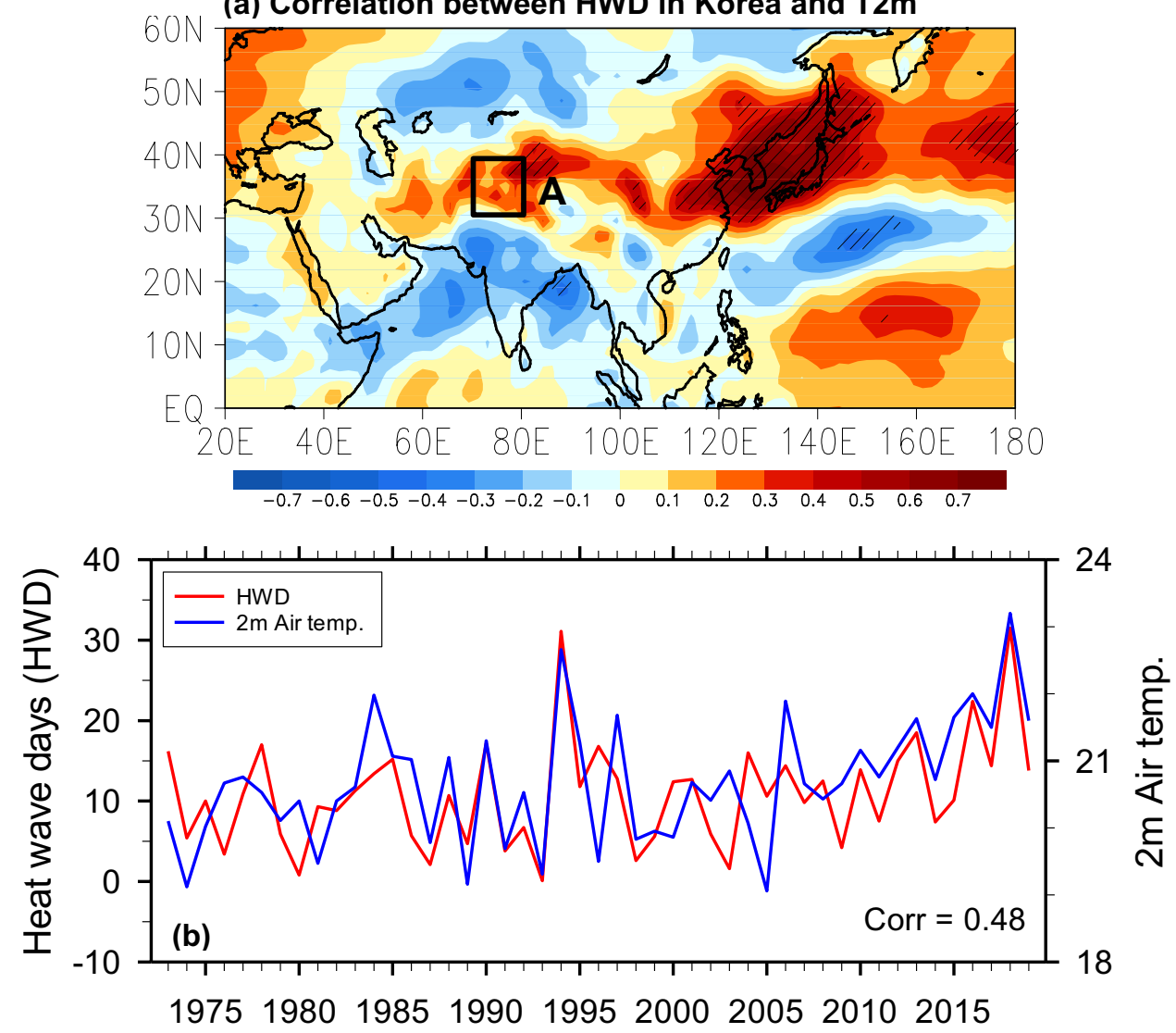

processes and ocean thermal conditions significantly influence the ISM and EASM (Huang et al. 2012). The SAH is affected by the Indian Ocean SST, and the relationship between the ISM and EASM is modulated by the El NiñoSouthern oscillation.

In addition, the differences in SST between the two groups were investigated (Fig. 14e). The analysis showed the eastern Pacific (EP) La Niña, in general, the cause of which requires further investigation. A La Niña usually corresponds to a strengthened ISM, which is conducive to more HWDs in Korea (Zhang et al. 1999). In particular, the sea areas around Korea and Japan showed strong warm anomalies, possibly because of a strong anomalous anticyclone in this region, low precipitation, and an increase in solar radiation. This strong warm anomaly that appears in the sea areas near Korea can increase the discomfort index by providing heat and moisture to coastal areas of Korea.

\subsection{Extreme case analysis}

The years of the highest and lowest frequencies in the HWD time series were selected, and the above results were analyzed for these two years (Fig. 15). The highest and lowest HWD frequencies occurred in 2018 and 1993, respectively. To examine the unique characteristics of these two years, the differences between the climatology and these two years were analyzed. First, the T2m values in 2018 showed a warm anomaly from the Iranian Plateau and the northern region of India to Central China, Korea, and Japan (left panel Fig. 15a), which was similar to the pattern of the above regression of $\mathrm{T} 2 \mathrm{~m}$ against the $\mathrm{SAH}$ index. The pattern in 1993 was the near opposite of that in 2018 and showed a cold anomaly in the $30^{\circ}-50^{\circ} \mathrm{N}$ region (right panel Fig. 15a). The correlation between these two patterns showed a negative correlation of -0.52 . Precipitation in 2018 showed a negative anomaly from the west to east from the northern region of India to Central China, Korea, and Japan (left panel Fig. 15b), but a positive anomaly in India, Indochina peninsula, South China Sea (SCS), and eastern sea of the Philippines, which resembled the results presented above regarding the differences in precipitation between the two groups. The pattern observed in 1993 exhibited a spatial distribution opposite to that observed in 2018, and the pattern correlation between these two spatial distributions had a negative correlation of -0.77 (right panel Fig. 15b). The SST in 2018 showed a central Pacific (CP) El Niño in general and a warm anomaly from west to east from the sea near Korea to the North American western sea (left panel of Fig. 15c). This latter case resembled the SST differences between the two groups. In 1993, EP El Niño appeared in general, and 

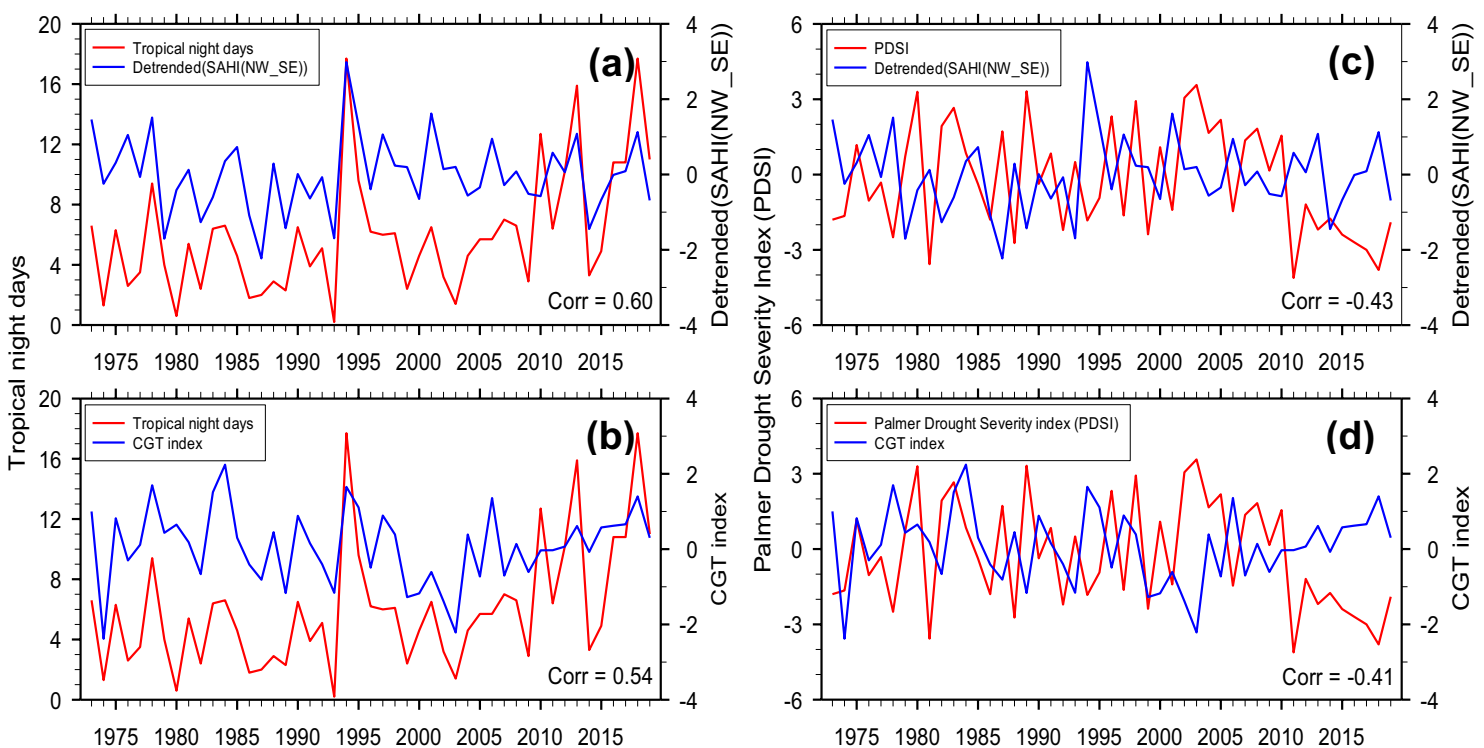

(e) Sea surface temperature (SST)

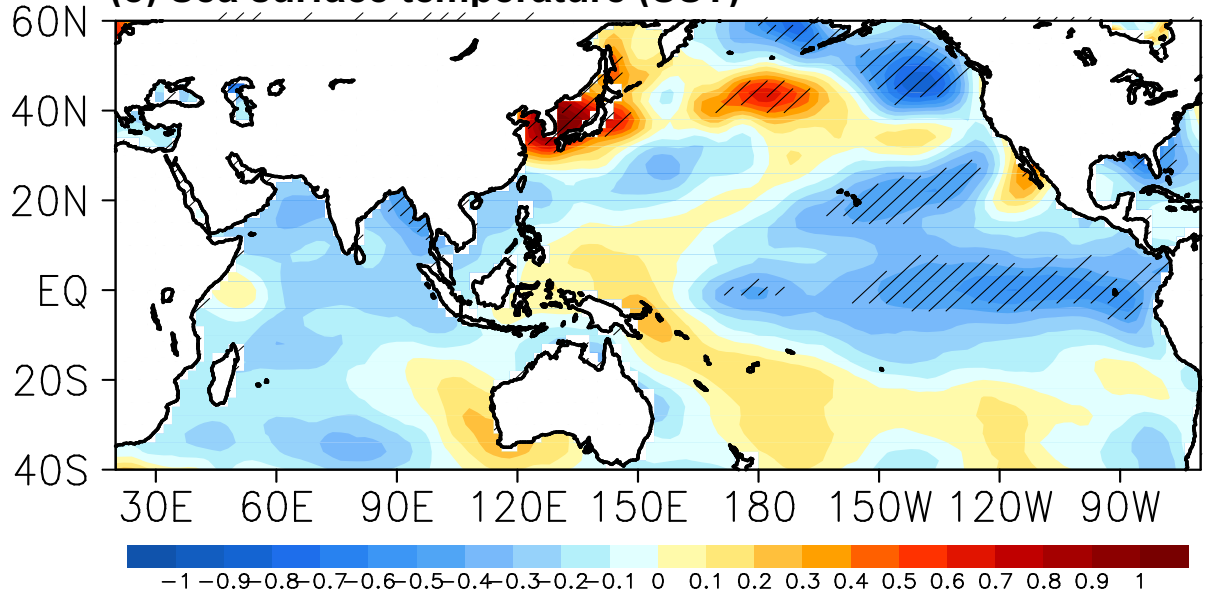

Fig. 14 Time series of a tropical night days (TND) in Korea and SAH index, b TND in Korea and CGT index, c Palmer Drought Severity Index (PDSI) in Korea and SAH index, and d PDSI in Korea and

a cold anomaly was observed in the west to east direction from seas near Korea and Japan to the north Pacific region. The pattern correlation between these two spatial distributions showed a negative correlation of -0.43 . In the case of the $200 \mathrm{hPa}$ stream flows in 2018, anomalous anticyclones existed in Korea, North Pacific, North America, Western Europe, and the Iranian Plateau (left panel of Fig. 15d). This spatial distribution was similar to the spatial distribution of the difference in the $200 \mathrm{hPa}$ stream flows between the two groups. Furthermore, the spatial distribution in 1993 was opposite of that observed in 2018 (right panel of Fig. 15d). Thus, the two spatial distributions showed a negative pattern correlation of -0.75 . The TC tracks did not influence Korea in 2018 because the TCs moved from the eastern sea of the Philippines to Central China and northern or southern China (left panel of Fig. 15e), which is similar to that
CGT index. e Composite difference in SST between the positive SAH years and negative SAH years. In $\mathbf{e}$, the dashed areas are significant at the $95 \%$ confidence level

observed for TCPF differences between the two groups. In 1993, however, TCs had a substantial impact on Korea (right panel of Fig. 15e).

\section{Summary and conclusions}

The SAH indices were defined using the $200 \mathrm{hPa}$ geopotential height average for 1973-2019, and the SAH centers were defined using four areas: A-area $\left(27.5^{\circ}-32.5^{\circ} \mathrm{N}, 55^{\circ}-75^{\circ} \mathrm{E}\right)$, B-area $\left(27.5^{\circ}-32.5^{\circ} \mathrm{N}, 85^{\circ}-105^{\circ} \mathrm{E}\right), \mathrm{C}$-area $\left(22.5^{\circ}-27.5^{\circ} \mathrm{N}\right.$, $\left.55^{\circ}-75^{\circ} \mathrm{E}\right)$, and $\mathrm{D}$-area $\left(22.5^{\circ}-27.5^{\circ} \mathrm{N}, 85^{\circ}-105^{\circ} \mathrm{E}\right)$. The differences between the east (BD-area) and west (AC-area) areas, between the south (CD-area) and north (AB-area) areas, between the southwest (C-area) and northeast (B-area) areas, and between the northwest (A-area) and southeast 
(a) $\mathrm{T} 2 \mathrm{~m}$
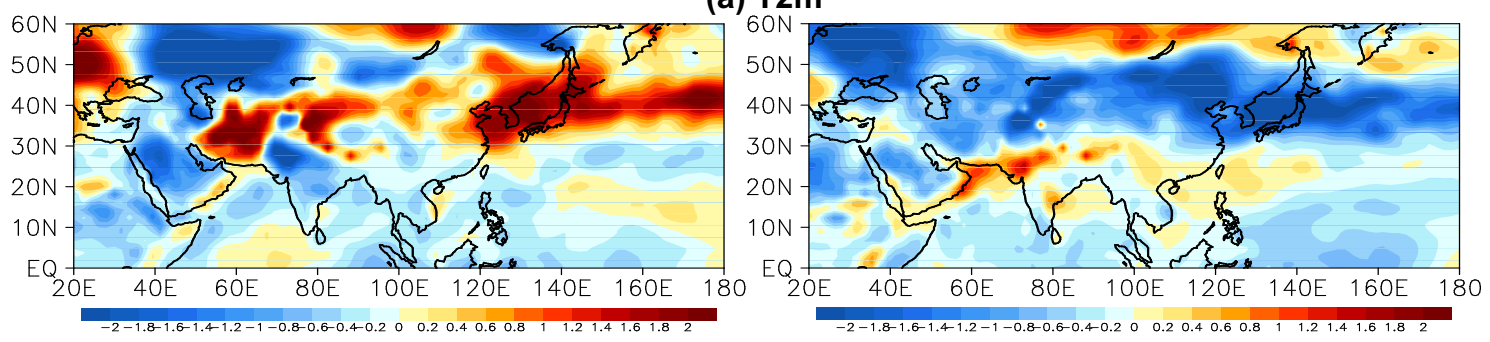

(b) Precipitation
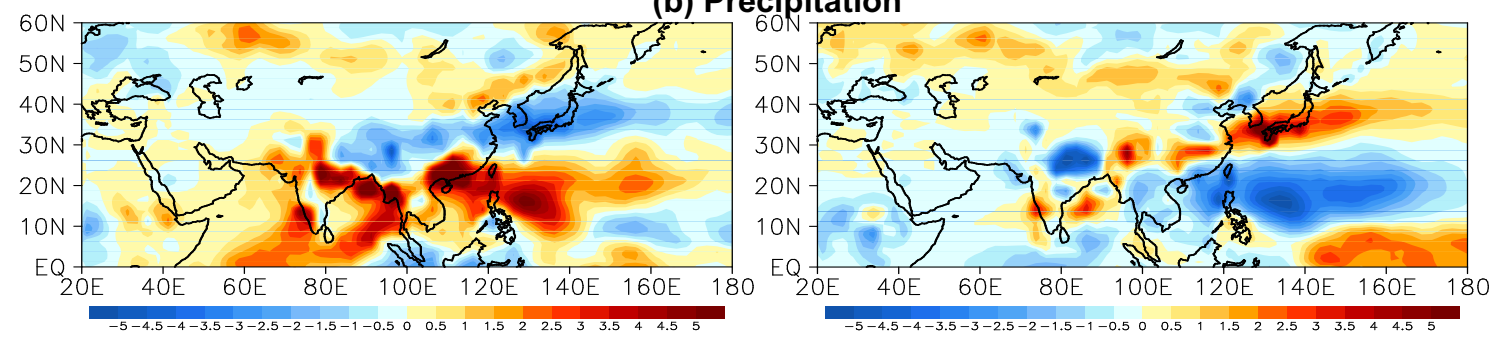

(c) SST

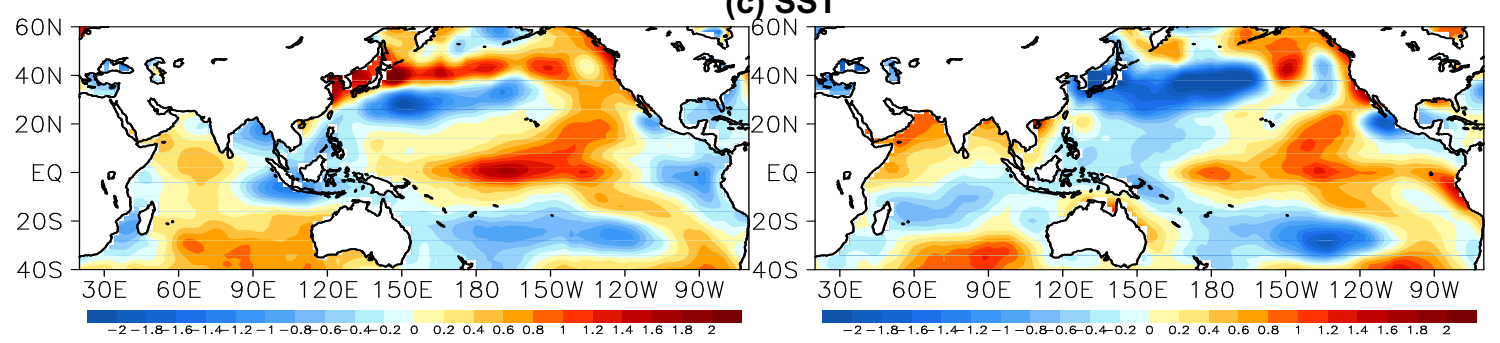

(d) $200 \mathrm{hPa}$ stream flows
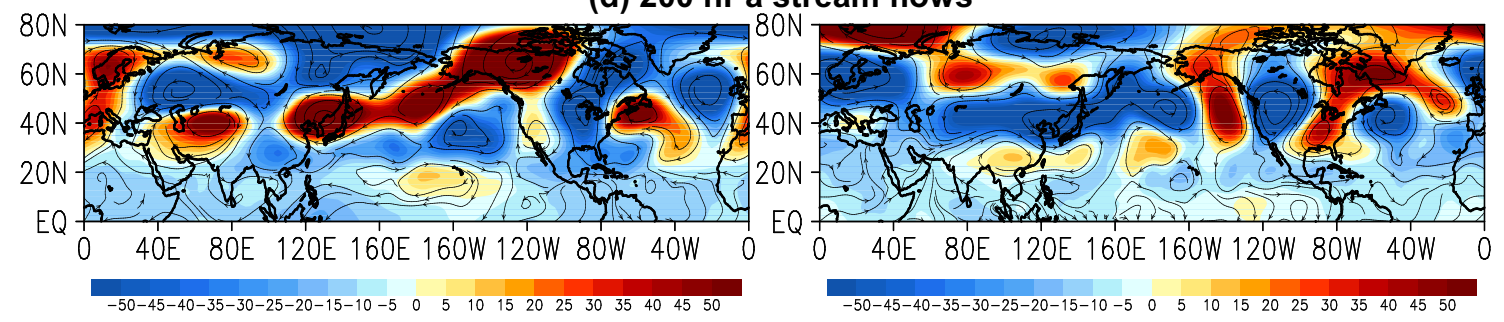

(e) TC track

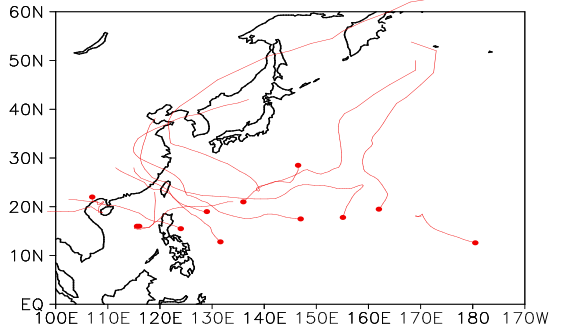

Fig. 15 Differences in a T2m, b precipitation, c SST, and d $200 \mathrm{hPa}$ stream flow and $200 \mathrm{hPa}$ geopotential height between 2018 and climatology (left panel) and between 1993 and climatology (right

(D-area) areas were obtained using each of these four areaaveraged $200 \mathrm{hPa}$ geopotential heights. Subsequently, the correlations between the movements of the SAH center in the east-west, south-north, southwest-northeast, and northwest-southeast directions and the HWDs in Korea

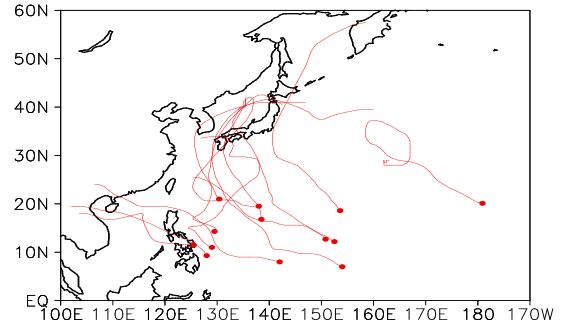

panel). e TC tracks in 2018 (left panel) and 1993 (right panel). Here, climatology indicates the average from 1973 to 2019 in JA

were examined using these four differences. The strongest correlation was found when the SAH center moved in the northwest-southeast direction. Hence, the SAH index was defined as the difference between the $200 \mathrm{hPa}$ geopotential heights in the northwest and southeast regions. 
Fig. 16 Schematic diagram of $200 \mathrm{hPa}$ anomalous atmospheric circulations occurring during the positive SAH years. "AH" indicates an anomalous high

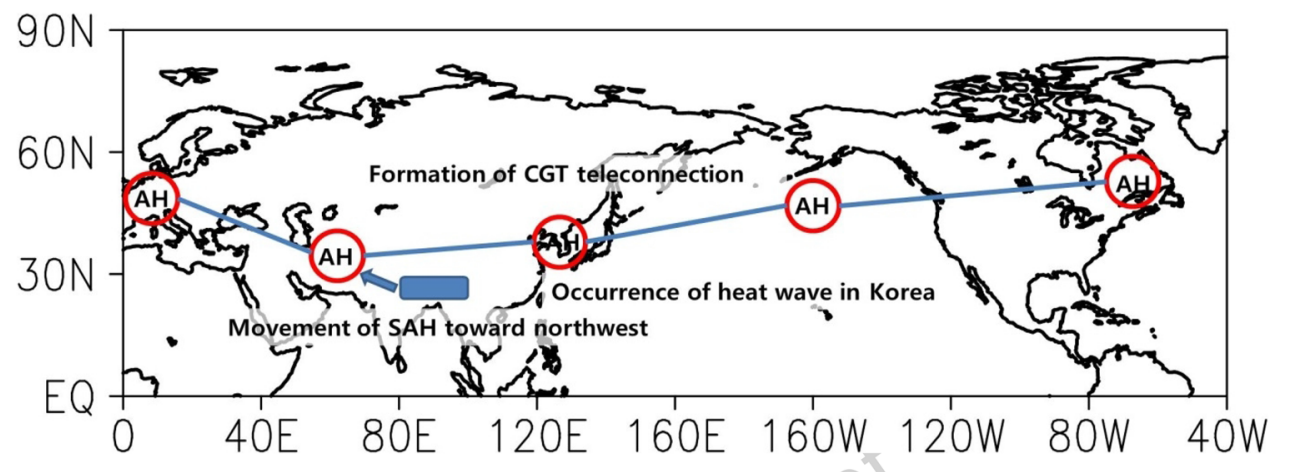

The diabatic heating effect of ISM precipitation is enhanced

The South Asian high is developing toward the northwest of India

Positive CGT pattern is formed

Anomalous high at all levels is located over Korea

Heat wave, tropical night, and drought occur in Korea
Thirteen years with a high SAH index and linear trend removed (positive SAH years) and 13 years with a low SAH index with linear trend removed were selected, and the differences between the averages of positive and negative SAH years were analyzed. The differences in specific humidity between the two groups were examined. A spatial distribution with a wave train shape was observed, i.e., a positive anomaly in the northwestern region of India, a negative anomaly in West China, and a positive anomaly from Central China to Korea and Japan. The discomfort index was extremely high during the positive SAH years in northeast Asia, including Korea, because of high T2m and specific humidity.

The difference in vertical meridional circulation averages along $120^{\circ}-130^{\circ} \mathrm{E}$, where Korea is located, was also analyzed. At $25^{\circ}-35^{\circ} \mathrm{N}$, anomalous high pressures and anomalous downward flows formed, and their centers were distributed in $30^{\circ}-35^{\circ} \mathrm{N}$, which also contains South Korea. This indicated that during the positive SAH years, there was a favorable environment in which the heatwaves could increase because high pressures were present in all layers of the Korean troposphere. Furthermore, positive anomalies of air temperature and specific humidity were distributed in $30^{\circ}-50^{\circ} \mathrm{N}$, and their centers were in $30^{\circ}-40^{\circ} \mathrm{N}$.

The spatial distributions of the SAH and WNPSH were examined in the two groups. First, during the positive SAH years, the $\mathrm{SAH}$ was located in $20^{\circ}-40^{\circ} \mathrm{N}$ in the meridional direction and extended to the eastern waters of Japan in the zonal direction. The WNPSH extended to the northwest of the Shandong Peninsula. As a result, the two high-pressure systems overlapped in Korea. During the negative SAH years, the SAH extended more to the southeast than in the positive SAH years, and the WNPSH extended to the southwest. As a result, the two high-pressure systems overlapped in South China.

The differences in stream flows and geopotential heights between the two groups were also analyzed. In general, during the positive SAH years, anomalous anticyclones developed in Korea, North Pacific, North America, Western Europe, and the Iranian Plateau. These anticyclones show the wavenumber-5 pattern and a barotropic vertical structure that became more distinct at higher altitudes. This spatial distribution was similar to the CGT pattern discovered by Ding and Wang $(2005,2011)$ (Fig. 16), who suggested that maintenance of the CGT patterns depends on the interaction between the CGT circulation and the ISM, which has a major effect on the mid-latitude atmosphere. ISM strengthening generates an upper-level anomalous anticyclone in the northwestern region of India and a continuous downstream of cells along the waveguide through the Rossby wave dispersion. In short, the ISM substantially influences the CGT patterns. Accordingly, this study analyzed the differences in precipitation between the two groups. A negative anomaly was formed from southwest to northeast from the 
northeastern region of India to Central China and then to Korea and Japan, whereas a positive anomaly was formed in the Indochina Peninsula, SCS, and the eastern Philippines. In contrast, the Indian subcontinent showed a positive anomaly. A negative anomaly formed from Central China to Korea and Japan during the positive SAH years, implying EASM weakening. The positive anomaly formed in the eastern Philippines and was associated with WNPSM strengthening.

According to Ding and Wang (2005, 2011), the effects of diabatic heating of ISM precipitation maintain the center of action in the northwestern region of India. Therefore, the CGT index was defined by the $200 \mathrm{hPa}$ geopotential height averaged for the northwestern region of India, and the correlation between SAH and CGT indices was analyzed. These two variables showed a positive correlation of 0.51 , meaning that the CGT pattern developed (weakened) when the SAH strengthened to the northwest (southeast).

This study analyzed the correlations between the TNDs in Korea and the SAH and CGT indices. The TNDs and SAH or CGT indices showed positive correlations of 0.60 and 0.54 , respectively. This suggests that the TNDs, like the HWDs, are strongly correlated with the ISM variations and resulting CGT patterns.

Acknowledgements This work was funded by the Korea Meteorological Administration Research and Development Program "Enhancement of Convergence Technology of Analysis and Forecast on Severe Weather" under Grants (KMA2018-00121).

Open Access This article is licensed under a Creative Commons Attribution 4.0 International License, which permits use, sharing, adaptation, distribution and reproduction in any medium or format, as long as you give appropriate credit to the original author(s) and the source, provide a link to the Creative Commons licence, and indicate if changes were made. The images or other third party material in this article are included in the article's Creative Commons licence, unless indicated otherwise in a credit line to the material. If material is not included in the article's Creative Commons licence and your intended use is not permitted by statutory regulation or exceeds the permitted use, you will need to obtain permission directly from the copyright holder. To view a copy of this licence, visit http://creativecommons.org/licenses/by/4.0/.

\section{References}

Adler RF, Huffman GJ, Chang A, Ferraro R, Xie P, Janowiak J, Rudolf B, Schneider U, Curtis S, Bolvin D, Gruber A, Susskind J, Arkin P, Nelkin E (2003) The Version-2 Global Precipitation Climatology Project (GPCP) Monthly Precipitation Analysis (1979-Present). J Hydrometeorol 4:1147-1167

Anderson BG, Bell ML (2009) Weather-related mortality: how heat, cold, and heat waves affect mortality in the United States. Epid 20:205-213

Byun HR, Hwang HS, Go HY (2006) Characteristics and synoptic causes on the abnormal heat occurred at Miryang in 2004. Atmosphere 16:187-201 ((in Korean with English abstract))

Choi BC, Kim J, Lee DG, Kysely J (2007) Long-term trends of daily maximum and minimum temperatures for the major cities of
South Korea and their implications on human health. Atmosphere 17:171-183 ((in Korean with English abstract))

Ding Q, Wang B (2005) Circumglobal teleconnection in the Northern Hemisphere Summer. J Clim 18:3483-3505

Ding Q, Wanf B, Wallace JM, Branstator G (2011) Tropical-extratropical teleconnections in boreal summer: observed interannual variability. J Clim 24:1878-1896. https://doi.org/10.1175/2011J CLI3621.1

Fink AH, Brücher T, Krüger A, Leckebusch GC, Pinto JG, Ulbrich U (2004) The 2003 European summer heatwaves and drought-synoptic diagnosis and impacts. Weather 59:209-216

Garcia-Herrera R, Diaz J, Trigo RM, Luterbacher J, Fischer EM (2010) A review of the European Summer heat wave of 2003. Crit Rev Environ Sci Tech 40:267-306

Ha KJ, Ha EH, Yoo CS, Jeon EH (2004) Temperature trends and extreme climate since 1909 at big four cities of Korea. Asia-Pac J Atmos Sci 40:1-16 ((in Korean with English abstract))

Ha KJ, Seo YW, Lee JY, Kripalani RH, Yun KS (2018) Linkages between the South and East Asian summer monsoons: a review and revisit. Clim Dyn 51:4207-4227. https://doi.org/10.1007/ s00382-017-3773-z

Hsu PC, Lee JY, Ha KJ (2016) Influence of boreal summer intraseasonal oscillation on rainfall extremes in southern China. Int J Climatol 36:1403-1412. https://doi.org/10.1002/joc.4433

Hsu PC, Lee JY, Ha KJ, Tsou CH (2017) Influences of boreal summer intraseasonal oscillation on heat waves in Monsoon Asia. J Clim 30:7191-7211. https://doi.org/10.1175/JCLI-D-16-0505.1

Huang R, Chen J, Wang L, Lin Z (2012) Characteristics, processes, and causes of the spatio-temporal variabilities of the East Asian monsoon system. Adv Atmos Sci 29:910-942. https://doi.org/10. $1007 / \mathrm{s} 00376-012-2015-\mathrm{x}$

Hulme M, Zhao ZC, Jiang T (1994) Recent and future climate change in East Asia. Inter J Climatol 14:637-658

IPCC. 2013: Summary for Policymakers. In: Climate Change 2013, The Physical Science Basis. Contribution of Working Group I to the Fifth Assessment Report of the Intergovernmental Panel on Climate Change [Stocker TF, Qin D, Plattner G-K, Tignor M, Allen SK, Boschung J, Nauels A, Xia Y, Bex V, Midgley PM (eds.)]. Cambridge University Press, Cambridge, United Kingdom and New York, NY, USA

Kalnay E, Kanamitsu M, Kistler R et al (1996) The NCEP/NCAT 40-year reanalysis project. Bull Am Meteorol Soc 77:437-471

Kim YS, Hong SK (1996) A study of quasi-Foehn in the Youngdongdistrict in late spring of early Summer. Asia Pac J Atmos Sci 32:593-600 ((in Korean with English abstract))

Kim HG, Min KD, Yoon IH, Moon YS, Lee DI (1998) Characteristics of the extraordinary high temperature events occurred in Summers of 1987 and 1994 over the Korean Peninsula. Asia-Pac J Atmos Sci 34:47-64 ((in Korean with English abstract))

Kim JA, Kim KR, Lee CC, Sheridan SC, Kalkstein LS, Kim BJ (2016) Analysis of occurrence distribution and synoptic pattern of future heat waves in Korea. J Clim Res 11:15-27 ((in Korean with English abstract))

Klinenberg E (1999) Denaturalizing disaster: a social autopsy of the 1995 Chicago heat wave. Theory Soc 28:239-295

Knowlton K, Rotkin-Ellman M, King G, Margolis HG, Smith D, Solomon G, Trent R, English P (2009) The 2006 California heat wave: impacts on hospitalization and emergency department visits. Envir Heal Persp 117:61-67

Kysely J, Kim J (2009) Mortality during heat waves in South Korea, 1991 to 2005: how exceptional was the 1994 heat wave? Clim Res 38:105-116

Lee JY (2018) Interdecadal changes in the boreal summer tropicalextratropical teleconnections occurred around mid-to-late 1990s. Atmosphere 28:325-336. https://doi.org/10.14191/Atmos.2018. 28.3.325(inKoreanwithEnglishabstract) 
Lee JY, Ha KJ (2015) Understanding of interdecadal changes in variability and predictability of the Northern Hemisphere summer tropical-extratropical teleconnection. J Clim 23:8634-8647. https://doi.org/10.1175/JCLI-D-15-0154.1

Lee JY, Wang B, Ding Q, Ha KJ, Ahn JB, Kumar A, Stern B, Alves O (2011) How predictable is the Northern Hemisphere summer upper-tropospheric circulation? Clim Dyn 37:1189-1203. https:// doi.org/10.1007/s00382-010-0909-9

Lee JY et al (2017) The long-term variability of Changma in the East Asian summer monsoon system: a review and revisit. Asia-Pac J Atmos Sci 53:257-272. https://doi.org/10.1007/ s13143-017-0032-5

Lee JY, Hsu PC, Moon S, Ha KJ (2017) Influence of boreal summer intraseasonal oscillation on Korean precipitation and its longterm changes. Atmosphere 27:435-444. https://doi.org/10.14191/ Atmos.2017.27.4.435 ((in Korean with English abstract))

Lee JY, Kim HJ, Jeong YR (2019) Influence of boreal summer intraseasonal oscillation on the 2016 heat wave over Korea (in Korean with English abstract)

Li JP, Zeng QC (2002) A unified monsoon index. Geophys Res Lett 29:1274. https://doi.org/10.1029/2001GL013874

Li JP, Zeng QC (2003) A new monsoon index and the geographical distribution of the global monsoons. Adv Atmos Sci 20:299-302

Li JP, Zeng QC (2005) A new monsoon index, its interannual variability and relation with monsoon precipitation. Clim Environ Res 10:351-365

Meehl GA, Tebaldi C (2004) More intense, more frequent, and longer lasting heat waves in the 21st century. Sci 305:994-997

Robine JM, Cheung SLK, Roy SL, Oyen HV, Griffiths C, Micheal JP, Herrmann FR (2008) Death toll exceeded 70,000 in Europe during the summer of 2003. Comp Rend Biolo 331:171-178

Schär C, Vidale PL, Lüthi D, Frei C, Häberli C, Liniger MA, Appenzeller C (2004) The role of increasing temperature variability in European summer heatwaves. Nature 427:332-336
Semenza JC, Rubin CH, Falter KH, Selanikio JD, Flanders WD, Howe HL, Wilhelm JL (1996) Heat-related deaths during the July 1995 heat wave in Chicago. N Engl J Medic 335:84-90

Smith TM, Reynolds RW, Peterson TC, Lawrimore J (2008) Improvements to NOAA's historical merged Land-Ocean surface temperature analysis (1880-2006). J Clim 21:2283-2296

Wei W, Zhang R, Wen M (2012) Meridional variation of South Asian High and its relationship with the summer precipitation over China. J Appl Meteorol Sci 23:650-659 ((in Chinese))

Wei W, Zhang R, Wen M, Rong X, Li T (2014) Impact of Indian summer monsoon on the South Asian High and its influence on summer rainfall over China. Clim Dyn 43:1257-1269

Wei W, Zhang R, Wen M, Kim BJ, Nam JC (2015) Interannual variation of the South Asian high and its relation with Indian and East Asian Summer Monsoon Rainfall. J Clim 28:2623-2634

Yeh SW, Won YJ, Hong JS, Lee KJ, Kwon M, Seo KH, Ham YG (2018) The record-breaking heat wave in 2016 over South Korea and its physical mechanism. Mon Weather Rev 146:1463-1474. https://doi.org/10.1175/MWR-D-17-0205.1

Yeh D, Gao Y (1979) Meteorology of the Tibetan Plateau (in Chinese). Science Publication Agency, 278 pp

Yeo SR, Yeh SW, Lee WS (2019) Two types of heat wave in Korea associated with atmospheric circulation pattern. J Geophys ResAtmos 124:7498-7511

Zhang RH, Sumi A, Kimoto M (1999) A diagnostic study of the impact of El Niño on the precipitation in China. Adv Atmos Sci 16:229241. https://doi.org/10.1007/BF02973084

Zhou F, Zhang R, Han J (2020) Influence of the East Asian summer monsoon on circumglobal teleconnection. J Clim 33:5213-5221

Publisher's Note Springer Nature remains neutral with regard to jurisdictional claims in published maps and institutional affiliations. 